\title{
Microfinance and the Corporate Governance Conundrum
}

\author{
Umakanth Varottil ${ }^{*}$
}

Microfinance evolved as an instrument to reduce poverty and bring about sustainable economic development. As an alternative to traditional means of finance such as banking and insurance, which failed to meet the needs of poorer sections of society, microfinance was pioneered by self-help groups, non-governmental organizations, and other nonprofit institutions. However, with a view to building a scalable model that engenders overall sustainable economic development, the microfinance sector has witnessed the emergence of for-profit institutions that are structured along the lines of the modern business corporation. These microfinance companies adopt market-based mechanisms to raise capital that is employed in financing the poor and less-privileged.

From a corporate governance perspective, microfinance companies and their boards of directors are faced with the classic dilemma. On the one hand, the principal goal of microfinance is to reduce poverty; to that extent the interests of borrowers (or customers) as principal stakeholders becomes paramount. On the other hand, a shareholder-centric approach operates as a major countervailing factor by compelling microfinance companies to generate profits to service investors and maintain stock price. The current discourse in corporate governance does not appear to satisfactorily address the predicament of boards of microfinance companies, as investors and stock markets judge the companies against the same standards generally applicable in the corporate sector.

This Article argues that the employment of conventional concepts and doctrines in corporate governance to for-profit microfinance companies does not adequately address the issues specific to such companies. It calls for a paradigm shift that necessitates examination of corporate governance in microfinance companies through an altogether different lens. After considering the available empirical evidence and analyzing qualitative data generated from

\footnotetext{
* Assistant Professor, Faculty of Law, National University of Singapore. I thank Jorge Esquirol, Dan Puchniak and Tarcila Reis for comments on a previous version of this Article, and Shruti Iyer for research assistance. I also thank Mukul Asher, Savita Shankar, M.S. Sriram and participants at the $8^{\text {th }}$ Asian Law Institute (ASLI) conference held at Fukuoka, Japan in May 2011 and the Institute for Global Law and Policy Workshop held at the Harvard Law School, United States in June 2011 for their valuable insights. My appreciation is also owed to several practitioners of microfinance in India who were generous with their time and ideas, but who cannot be named individually due to the understanding of anonymity. Needless to say, the views in this Article as well as any errors or omissions remain mine alone.
} 
Microfinance and the Corporate Governance Conundrum

case studies and field interviews, it seeks to develop separate parameters for measuring corporate governance and performance of microfinance companies, so that the overarching goals of reducing poverty are not diluted.

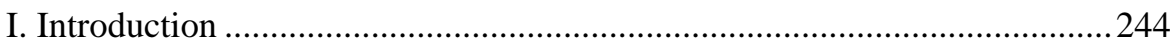

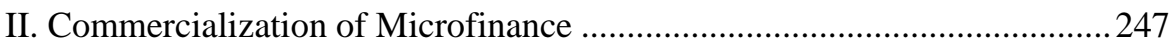

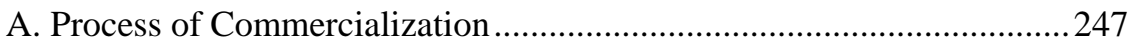

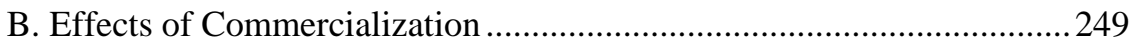

III. Corporate Governance Framework for Microfinance................................. 251

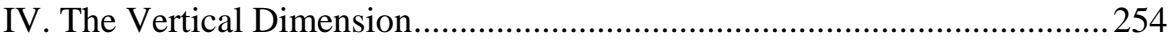

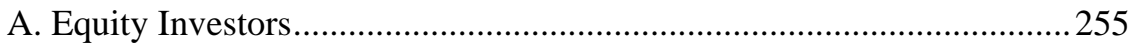

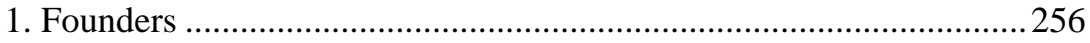

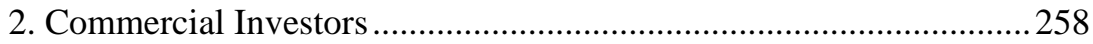

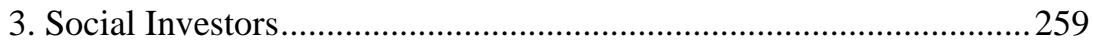

4. Investors in the Capital Markets .......................................................261

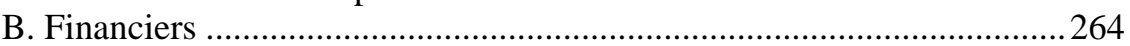

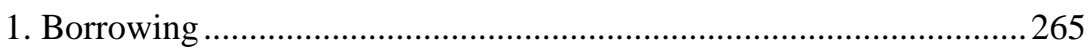

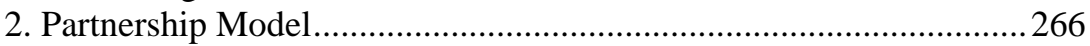

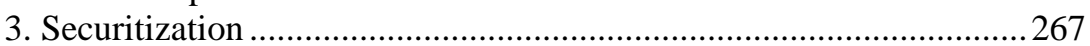

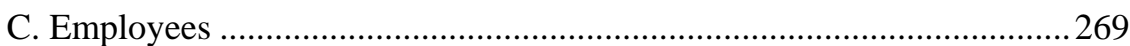

D. Taking Stock of Capital Providers' Incentives......................................227

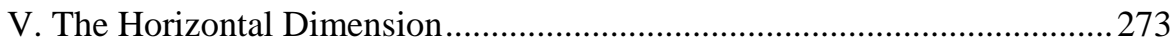

A. Social Impact of Commercial Microfinance ...........................................2273

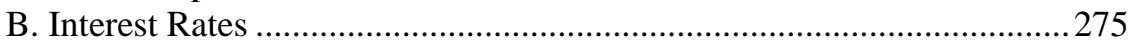

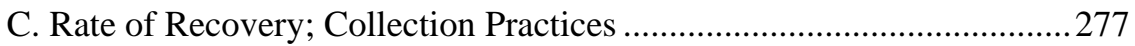

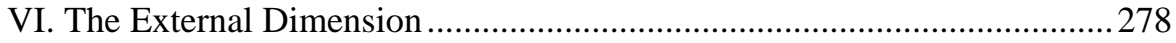

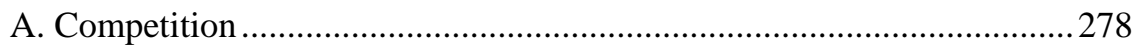

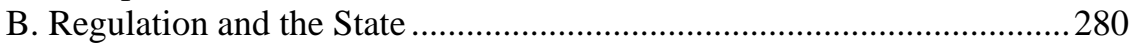

VII. Board Structure and Practices in MFIs....................................................... 282

A. Theoretical Framework; Corporate Governance Discourse ..................... 282

B. Board Composition and Focus..........................................................284

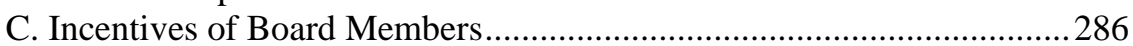

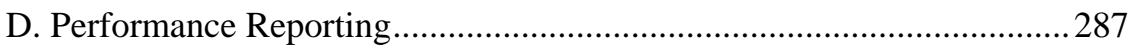

VIII. Alternative Corporate Governance Framework for MFIs .......................288

A. Clarity of Corporate Purpose and Mission ..............................................28

B. Moderating the Expectations of Capital Providers ..................................2289

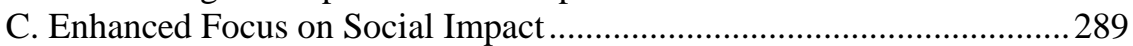

D. Method of Regulating Corporate Governance in MFI ............................2 291

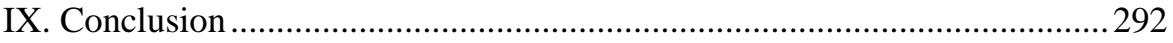




\section{INTRODUCTION}

The current wave of management thinking places considerable emphasis on the use of private-sector market-based arrangements to address developmental goals on a global scale. ${ }^{1}$ The effectiveness of governments and nongovernmental actors is limited by constraints on resources and reach. The power of capitalism, it is said, can be harnessed to combat problems such as poverty and the lack of basic education and healthcare by delivering products and services on a commercial scale to communities that have been traditionally isolated from mainstream markets. Concepts such as "creative capitalism,"2 "shared values," 3 and "bottom of the pyramid" (hereinafter "BoP") have gained rapid ascendancy in management and developmental discourses.

While these ideas continue to evoke conceptual debates, they have already found acceptance in practice in the field of microfinance. Microfinance evolved as an instrument to reduce poverty and bring about sustainable economic development. ${ }^{5}$ As an alternative to traditional means of finance, which failed to meet the needs of poorer sections of society, microfinance was pioneered by self-help groups, non-governmental organizations, and other nonprofit institutions. ${ }^{6}$ While this form of finance has attained a fair amount of popularity in the developing world, a key shortcoming was identified: the lack of a wider

\footnotetext{
${ }^{1}$ For a commonly understood enumeration of these goals, see United NATIONS DEV. PROGRAM, MiLLENNIUM DEV. GOALS, available at http://www.unmillenniumproject.org/reports/fullreport.htm.

${ }^{2}$ Bill Gates, A New Approach to Capitalism, in Creative CaPitalism 7, 9 (Michael Kinsley \& Connor Clarke eds., 2009) (stating that "[t]he genius of capitalism lies in its ability to make self-interest serve the wider interest.")

${ }^{3}$ Michael E. Porter \& Mark R. Kramer, Creating Shared Value, 89 HARV. Bus. ReV. 62, 64 (2011) (advocating "the principle of shared value, which involves creating economic value in a way that also creates value for society by addressing its needs and challenges.”).

${ }^{4}$ C.K. Prahlad, The Fortune at the Bottom of the Pyramid: Eradicating Poverty Through PROFITS 3-4 (2009) (noting "the idea that the private sector can and should be involved in creating market-based solutions for the world's poorest consumers is gaining credibility.") The focus is on the bottom of the pyramid, represented by the world's poor. Id.

${ }^{5}$ Microfinance refers to "small-scale financial services-primarily credit and savings-provided to people who farm or fish or herd; who operate small enterprises or microenterprises where goods are produced, recycled, repaired or sold; ... and to other individuals and groups at the local levels of developing countries, both rural and urban.” MARguerite S. ROBINSON, THE MiCROFinANCE REVOLUTION: SUSTAINABLE FINANCE FOR THE POOR 9 (2002). Although microfinance refers to a range of financial services such as credit, savings and insurance, it largely comprises microlending or microcredit. David Hulme, Is Microcredit Good for Poor People? A Note on the Dark Side of Microfinance, 11 SMALl ENTER. DEV. 26, 26 (2000)

${ }^{6}$ The genesis of microfinance in its popular form has been attributed to Muhammad Yunus who received the Nobel Peace Prize in 2006. It originated as a nonprofit activity and was carried almost entirely through subsidies and donations until the 1990s. See Connie Bruck, Millions for Millions, THE NEW YORKER, Oct. 2006, at 1, available at http://www.newyorker.com/archive/2006/10/30/ 061030fa_fact1.
} 
Microfinance and the Corporate Governance Conundrum

reach to generate a more meaningful impact on society ${ }^{7}$.

With a view to building a scalable model that engenders overall sustainable economic development, the microfinance sector has recently witnessed the emergence of for-profit institutions that are structured along the lines of the modern business corporation. These commercial microfinance institutions (MFIs) adopt market-based mechanisms to raise capital that is employed in financing the poor and less-privileged. While these MFIs raise debt from banks, they also raise risk-capital by issuing shares and other securities to private equity and venture capital investors, and even through initial public offerings that make their securities available for trading on stock exchanges.

Such efforts at raising finances impose demands on MFIs to service their lenders and investors. Arguably, the pressures to service their financial stakeholders and the consequential need to generate profits create incentives for MFIs to lend on commercial terms that cause a tight squeeze on underprivileged borrowers (who may be left with no option but to borrow on those terms). Recent anecdotal evidence from India reinforces the issue ${ }^{8}$ - wherein MFIs are alleged to have charged exorbitant interest rates on microloans, resulting in a major backlash against the industry with the State of Andhra Pradesh speedily enacting legislation that leaves the survivability of the industry in that state in doubt. ${ }^{9}$

From a corporate governance perspective, MFIs and their boards of directors are faced with the classic dilemma. On the one hand, it is recognized that the principal goal of microfinance is to reduce poverty; to that extent the interests of borrowers (or customers) as principal stakeholders becomes paramount. On the other hand, a shareholder-centric approach operates as a major countervailing factor that compels MFIs to generate profits to service investors and, in case of public listed MFIs, maintain stock price.

This Article argues that the employment of conventional concepts and doctrines in corporate governance to MFIs does not adequately address the issues specific to the sector. Conventional corporate governance framework

\footnotetext{
${ }^{7}$ Reinhard H. Schmidt, Microfinance, Commercialization and Ethics, 2 POVERTY \& PUB. POL’y 99, 103 (2010).

${ }^{8}$ This Article refers to the experience in India because the effects of commercialization of microfinance attracted significant attention in that country in recent years. While the lessons from the occurrences in India may be relevant in other countries as well, it would be necessary to place emphasis on the domestic legal system, economic and social conditions, cultural factors and other similar circumstances of each country before adapting them. In any event, the objective of this Article is to address the issues at a conceptual level using norms rather than to deal with the specific laws and regulations either in India or in any other country.

${ }^{9}$ Consultative Grp. to Assist the Poor, Andhra Pradesh 2010: Global Implications of the Crisis in Indian Microfinance 4, Focus Note No. 67 (2010), available at http://www.cgap.org/gm/document1.9.48945/FN67.pdf [hereinafter CGAP, Andhra Pradesh 2010]; Intellecap, Indian Microfinance Crisis of 2010: Turf War or a Battle of Intentions? 5 (Oct. 2010) [hereinafter Intellecap White Paper], available at http://www.intellecap.com/assets/82/Intellecap_Microfinance_White_Paper_Oct_2010_ .pdf.
} 
relies on the lure of financial returns to induce investors and financiers to provide capital to corporations. Such a framework places excessive dependence on the financial sustainability of MFIs. This framework also pays less heed to the social goals and outreach of MFIs, even though the evidence of better financial performance through commercialization is open to debate. ${ }^{10}$ By adopting market-based mechanisms such as public offering of shares-where there is anonymity of shareholding and possible short-termism —and securitization of portfolios, there is a fear that MFI activity carries several features of the subprime crisis that may result in the creation of a "microfinance bubble." Viewed through the conventional framework, the microfinance industry has also generated a perception of profiteering from the poor that has seriously impacted its credibility. ${ }^{11}$

Although the existing discourse on corporate governance does recognize broader stakeholder interests (beyond just shareholders), it has yet to receive the necessary impetus due to the heterogeneity of the interests of stakeholders such as creditors, employees, customers, and the community in general. In the microfinance sector, however, the external stakeholders are primarily the MFIs' customers - the poor and underprivileged borrowers. Because they (and their interests) are more easily identifiable, the criticism of the stakeholder approach would not apply to the microfinance sector.

There is therefore a need for a paradigm shift that necessitates examination of corporate governance in microfinance companies through an altogether different lens that provides equal importance to the social performance of MFIs and their impact on external stakeholders such as customers. New parameters must be developed to judge the financial and social performance of MFIs such that they are able to maintain their "double bottom lines" by achieving their social goals along with sustainable financial performance. ${ }^{12}$ The corporate governance framework must transcend beyond a "shareholder primacy" or "agency cost" approach into a "customer primacy" approach that maintains focus on the customers and the communities that MFIs serve. MFIs will have to be treated as social enterprises that are subject to different standards, where emphasis is placed on attracting investors with long-term goals and lesser expectations on commercial returns, and with a continued focus on social goals. Such a new framework will help restore the somewhat eroding glory of

\footnotetext{
${ }^{10}$ For a greater discussion of the empirical evidence, see infra Part IIB.

${ }^{11}$ Existing literature refers to this phenomenon as "mission drift" in microfinance, which is "a shift in the composition of new clients, or a re-orientation from poorer to wealthier clients among existing clients.” Robert Cull, Asli Demirguc-Kunt \& Jonathan Morduch, Financial Performance and Outreach: A Global Analysis of Leading Microbanks, 117 ECON, J. F107, F126 (2007) [hereinafter Cull, DemirgucKunt \& Morduch, Financial Performance and Outreach].

${ }^{12}$ Marc de Sousa Shields, Competing Business Models and the Microfinance Double Bottom Line, 16 MicrobANKING BULletin 6 (2008); Jonathan Morduch, The Microfinance Schism, 28 WoRLD DEV. 617, 617 (2000) [hereinafter Morduch, The Microfinance Schism].
} 
Microfinance and the Corporate Governance Conundrum

microfinance. ${ }^{13}$

Part II of this Article discusses the process of commercialization of the microfinance sector, and empirical evidence of its impact. Part III sets out the corporate framework within which the incentives of various players in the microfinance sector must be examined. Parts IV, V, and VI discuss the vertical, horizontal and external dimensions respectively that operate to influence the MFIs in maintaining a balance between financial sustainability and social impact. Part VII examines the board structure and practices in MFIs. Part VIII contains some normative suggestions to achieve the aforesaid balance, and Part IX concludes.

\section{COMMERCIALIZATION OF MiCROFINANCE}

In this Part, the Article provides an overview of the process of commercialization in the microfinance sector and analyzes available empirical evidence regarding its impact on financial sustainability and outreach.

\section{A. Process of Commercialization}

Microfinance was devised as a method of alleviating poverty by providing affordable credit to the poor that enables them to carry on income-generating activity. ${ }^{14}$ The initial phase of microfinance was dominated by nongovernmental organizations (NGOs) with extensive government support. ${ }^{15}$ Fund-raising was mainly in the form of donations and subsidized credit. ${ }^{16}$ While these arrangements aided in achieving some scale, financing was limited, leaving sustainability of the microfinance organizations in doubt. Often, funds from donors and subsidization of credit dried up. ${ }^{17}$ Moreover, the lack of appropriate incentives saw drastic drop in repayment rates of microloans (due to ineffectiveness in collections) and the diversion of credit to less-deserving

\footnotetext{
${ }^{13}$ The lessons from a study of corporate governance in the microfinance sector can also be easily transposed across other social sectors and sustainable businesses that operate with a view to maintaining "double bottom lines."

${ }^{14}$ It is a different matter that there is considerable skepticism as to whether microfinance by itself can make a dent on poverty. Alleviation of poverty requires other measures such as education, healthcare and other forms of social and financial inclusion. See Hulme, supra note 5, at 28. Nevertheless, the fact that microfinance has at least a minimal impact on reducing vulnerability to poverty is arguably beyond challenge. Disagreements are confined to the degree of impact rather than its existence.

${ }^{15}$ See Jonathan Morduch, The Microfinance Promise, 37 J. ECON. LiT. 1569, 1570 (1999) [hereinafter Morduch, The Microfinance Promise]; Robert Cull, Asli Demirguc-Kunt \& Jonathan Morduch, Microfinance Meets the Market, 23 J. ECON. PERSP. 167, 171 (2009) [hereinafter Cull, Demirguc-Kunt \& Morduch, Microfinance Meets the Market].

${ }^{16}$ Gaamaa Hishigsuren, Transformation of Micro-finance Operations from NGO to Regulated MFI 6-7, available at http://www.microcreditsummit.org/papers/Workshops/3_Hishigsuren.pdf/.

${ }^{17}$ M.S. Sriram, Commercialisation of Microfinance in India: A Discussion on the Emperor's Apparel, XLV ECON. \& Political WeEkLY, No. 24, Jun. 12, 2010, at 65, 66 [hereinafter Sriram, Commercialisation of Microfinance in India].
} 
customers occasioned by political imperatives. ${ }^{18}$ Unreliable financial performance and lack of scalability meant a substantial part of the demand for microfinance went unmet. ${ }^{19}$ The industry was compelled to seek solutions that provided low-cost credit with much greater outreach.

In a move towards financial sustainability and scale, the 1980s and 1990s witnessed the emergence of large for-profit MFIs. ${ }^{20}$ Multiple models of organization were adopted depending upon the domestic regulatory requirements within each country. For example, BancoSolidario (BancoSol) of Bolivia migrated from a donor-based nonprofit entity into a full-fledged MFI. ${ }^{21}$ Another oft-cited example is that of Bank Rakyat Indonesia (BRI), a stateowned company that has achieved "a high degree of financial selfsufficiency." 22 These MFIs focus on generation of profits like any other business, with the poor households being treated as mere customers. Although these institutions operate with the mission of achieving a "double bottom line", social goals have been relegated to a subsidiary position while financial sustainability objectives dominate management decision-making. These MFIs raise capital from development financial institutions, banks and increasingly from private investors.

The most recent form of commercialization of microfinance is represented by the public capital-raising activity of MFIs. A watershed event has been the initial public offering (IPO) of shares by Banco Compartamos of Mexico in 2007, which was accompanied by a listing of those shares now available for trading in the secondary markets. ${ }^{23}$ The transaction drew heavy criticism from the social sector. Professor Muhammad Yunus remarked: "I am shocked by the news about the Compartamos IPO. Microcredit should be about helping the poor to get out of poverty by protecting them from moneylenders, not creating new ones . . ..24 The fact that the public offering involved down-selling of

${ }^{18}$ Cull, Demirguc-Kunt \& Morduch, Microfinance Meets the Market, supra note 15, at 169.

${ }^{19}$ Morduch, The Microfinance Promise, supra note 15, at 1578-79.

${ }^{20}$ Roy Mersland \& R. Oystein Strom, Performance and Trade-offs in Microfinance Organizations Does Ownership Matter? (Working Paper, 2008), available at http://ssrn.com/abstract=970513 [hereinafter Mersland \& Strom, Performance and Trade-offs] (pointing to some of the benefits of forprofit institutions such as shareholder owned firms as they "can be regulated by banking authorities, accept deposits, provide a larger range of better quality services, be independent from donors, attract private equity capital and benefit from superior corporate governance because they are privately owned.").

${ }^{21}$ Morduch, The Microfinance Promise, supra note 15, at 1576; Sriram, Commercialisation of Microfinance in India, supra note 17, at 66.

${ }^{22}$ STEPHANiE CHARITONENKo \& ISMAH AFWAN, COMMERCIALIZATION OF MiCROFINANCE: INDONESiA $\mathrm{x}(2003)$.

${ }^{23}$ Elisabeth Rhyne \& Andres Guimon, The Banco Compartamos Initial Public Offering, 23 ACCION INSIGHT at 1 (Jun. 2007), available at http://resources.centerforfinancialinclusion.org/insight/IS23en .pdf.

${ }^{24}$ Milford Bateman, Why Doesn't Microfinance Work? The Destructive Rise of Local NEOLIBERALISM 144 (2010). 
Microfinance and the Corporate Governance Conundrum

shares by existing shareholders of the company (who profited from it) rather than capital raising by the company through offer of new shares did little to meet the criticism. ${ }^{25}$ Even before the din subsided, SKS Microfinance, an MFI in India, embarked on a public offering at attractive valuations and achieved listing of its shares on Indian stock exchanges. ${ }^{26}$ Other MFIs in India put themselves in a state of preparedness in a bid to replicate the success of SKS Microfinance, although no further public offering of an MFI has in fact occurred in India due to unfavorable market conditions for microfinance companies $^{27}$ during the period that ensued after the SKS IPO. ${ }^{28}$

These developments indicate that the microfinance sector has undergone metamorphosis whereby its initial operation, principally run on nonprofit basis and with developmental objectives, has given way to a rising role played by market-based institutions that maintain an eye on financial sustainability through profits. ${ }^{29}$

\section{B. Effects of Commercialization}

Since commercialization of microfinance is a relatively recent phenomenon, its impact on the trade-off between financial sustainability and social goals is hard to measure. However, there is a burgeoning body of literature that examines the issue from an empirical standpoint, and it would be appropriate to briefly dwell upon this literature before discussing the trade-off in detail.

Although advocates of a market-based approach have long argued in favor of commercialization as they claim that it brings about superior financial

${ }^{25}$ See Richard Rosenberg, CGAP Reflections on the Compartamos Initial Public Offering: A Case Study on Microfinance Interest Rates and Profits 2-3, FoCUS NOTE No. 42 (2007).

${ }^{26}$ N. Srinivasan, Microfinance India: State of the Sector Report 2010, SAGE IMPACT 6 (2010) (observing that "[a] less than five year old institution mobilizing \$350 million from the capital market at a price that is more than six times its book value is a major milestone in the sector's journey.”).

${ }^{27}$ Keshav Garud, Microfinance in Andhra Pradesh, India in the Wake of Government Sanctions: A Look at Institutions and Borrowers (Jan. 10, 2013), available at http://www.sirjournal.org/2013/01/10/ microfinance-in-andhra-pradesh-india-in-the-wake-of-government-sanctions-a-look-at-institutions-andborrowers-2/ ("In light of these concerns, and the 2010 crisis, SKS and other microfinance institutions in Andhra Pradesh face an uphill battle. As a consequence of government-enforced mass defaults, the entire system of financing the microfinance institutions buckled under. Bank debt financing and equity investment in microfinance institutions decreased dramatically as confidence in the microfinance sector decreased. The size of microfinance institutions has drastically shrunk because of the mass defaults in 2010.”).

${ }^{28}$ Rina Chandran \& Pratish Narayanan, SKS IPO Success Heralds More Microfinance Offers, REUTERS, Aug. 3, 2010, available at http://in.reuters.com/article/2010/08/03/idINIndia-50584520100803.

${ }^{29}$ That is not to say that for-profit MFIs are dominating the microfinance sector. Nonprofit institutions, governmental bodies, banks, cooperatives, and self-help groups continue to play a large role in microfinance, and it is by no means the case that for-profit MFIs have overshadowed the role of nonprofit institutions. Nevertheless, for-profit MFIs have witnessed exponential growth in number and size in recent years. On the whole, the microfinance industry is extremely heterogeneous in its organizational types. See Kenneth Anderson, Microcredit: Fulfilling or Belying the Universalist Morality of Globalizing Markets?, 5 YALE HUM. RTS. \& DEV. L.J. 85, 102 (2002). 
performance, there is scant empirical evidence supporting this argument. One study indicates that the difference between shareholder-owned firms and NGOs in terms of financial performance is minimal, indicating that there is no preference for one type of ownership or the other in the industry. ${ }^{30}$ This goes to show that the motivations of organizations need not necessarily depend on their type: some NGOs may be more commercially oriented than for-profit firms, while some for-profit firms may be more socially focused than NGOs. ${ }^{31}$ Other studies $^{32}$ have been able to identify "a basic tension between meeting social goals and maximizing financial performance," ${ }^{33}$ which entails trade-offs. One such study finds that "non-profit microfinance institutions make far smaller loans on average and serve more customers than do commercialized microfinance banks, but their costs per dollar lent are also much higher." ${ }^{\text {"3 }}$ This is supported by another study revealing that nonprofit organizations have smaller loan sizes (although not necessarily in number) and service more women. ${ }^{35}$ These indicate a greater preference for social goals over financial sustainability within the nonprofit sector when compared with for-profit institutions. ${ }^{36}$ In sum, there is no overwhelming evidence that supports a wholesale transition to commercialization of the microfinance sector, either on the ground of a "win-win" proposition or even solely on the ground of financial sustainability. ${ }^{37}$

Given the limitations to commercialization, there have been calls for "a more constructive dialogue between microfinance advocates that privilege financial development and those that privilege social impacts" ${ }^{\text {"3 }}$, as many such

\footnotetext{
${ }^{30}$ Mersland \& Strom, Performance and Trade-offs, supra note 20, at 2.

${ }^{31} \mathrm{Id}$. at 5 .

${ }^{32}$ Robert Cull, Asli Demirguc-Kunt \& Jonathan Morduch, Microfinance Tradeoffs: Regulation, Competition, and Financing 1 (Fin. Acesss Initiative, Working Paper, 2009), available at http://financialaccess.org/sites/default/files/FAI_Microfinance_Tradeoffs.pdf [hereinafter Cull, Demirguc-Kunt \& Morduch, Microfinance Tradeoffs]; Roy Mersland, The Cost of Ownership in Microfinance Organizations, 37(2) WORLD DEV. 469 (2009) [hereinafter Mersland, The Cost of Ownership].

${ }^{33}$ Cull, Demirguc-Kunt \& Morduch, Microfinance Tradeoffs, supra note 32, at 1.

${ }^{34} \mathrm{Id}$.

${ }^{35}$ Mersland, The Cost of Ownership, supra note 32, at 37.

${ }^{36}$ At the same time, it is well recognized that measuring social goals and outreach can be a daunting task. Parameters and perceptions may vary. Hence, academics and practitioners tend to use proxies such as loan size, number of borrowers, extent of women borrowers, and the like to measure outreach. See infra notes 129-132, and accompanying text.

${ }^{37}$ Morduch, The Microfinance Promise, supra note 15, at 1609 (lamenting that "the "win-win" rhetoric promising poverty alleviation with profits has moved far ahead of the evidence, and even the most fundamental claims remain unsubstantiated.”). However, one piece of evidence emanating from Pakistan suggests that, "given a supportive environment, it is possible for commercially-oriented microfinance banks to meet a 'double bottom line' of simultaneously pursuing profits and a social mission to promote development.” Heather Montgomery \& John Weiss, Can Commercially-oriented Microfinance Help Meet the Millennium Development Goals? Evidence from Pakistan, 39 WORLD DEV. 87, 107 (2011).

${ }^{38}$ Morduch, The Microfinance Schism, supra note 12, at 617.
} 
Microfinance and the Corporate Governance Conundrum

advocates strictly prefer one type of organizational form over the other. ${ }^{39}$ Drawing strands from this, in the following Parts, the Article uses the framework of corporate governance in the microfinance sector to examine how the schism that exists between proponents and opponents of commercialization may be addressed.

\section{CORPORATE GOVERNANCE FRAMEWORK FOR MICROFINANCE}

The importance of corporate governance to the microfinance sector has been emphasized in existing literature. It has been "identified as a key factor for enhancing the viability of the industry." ${ }^{40}$ However, the governance issues have been explored largely from the traditional paradigm of agency costs. This paradigm has become ubiquitous in theorizing the management and monitoring of business corporations. The principal objective of corporate governance norms is to reduce these agency costs. Corporate law theorists have identified three types of agency costs: (i) between the owners and managers, which come into play in a corporation with diffused shareholding; (ii) between controlling shareholders and minority shareholders, which are magnified in a corporation with concentrated shareholding; and (iii) between a company and its nonshareholder constituencies, referred to generally as stakeholders, such as employees, customers, creditors, local communities, and public authorities. ${ }^{41}$ While the first two types of agency costs have been the subject matter of extensive discussion, the stakeholder theory is yet to make a serious dent on conventional thought in corporate law and governance. ${ }^{42}$

The agency costs framework breaks down in its application to the microfinance sector, ${ }^{43}$ as this Article elaborates further. In addition to this framework, which would apply equally to an MFI as it would apply to any other business corporation, corporate governance in the microfinance sector must address the dual objectives of financial sustainability and social goals. The specific features of the microfinance sector, as we shall see in greater

\footnotetext{
${ }^{39}$ Id. at 619. Morduch also cautions against euphoric acceptance of the "win-win" vision, as it "has alienated many potential supporters.” Id. at 627.

${ }^{40}$ Roy Mersland, The Governance of Non-Profit Micro Finance Institutions: Lessons from History, J. MGMT. \& GOVERNANCE 113, 114 (forthcoming), available at http://ssrn.com/abstract=1298613.

${ }^{41}$ REINIER KRAAKMAN, ET. AL, THE ANATOMY OF CORPORATE LAW 36 (2009).

${ }^{42}$ A key reservation expressed by advocates of the shareholder-centric approach is the lack of homogeneity in the interests of the different types of stakeholders thereby causing difficulty in imposing enforceable duties on directors and managers of a corporation. See infra notes 187-190 and accompanying text. For a discussion in the context of the U.K. Companies Act of 2006, see Deryn Fisher, The Enlightened Shareholder - Leaving Stakeholders in the Dark: Will Section 172(1) of the Companies Act 2006 Make Directors Consider the Impact of Their Decisions on Third Parties, 20 I.C.C.L.R. 10, 10 (2009).

${ }^{43}$ While the microfinance sector constitutes the thrust of this Article, the corporate governance framework suggested herein may be extended to other social businesses as well.
} 
detail, place corporate governance in this field on "a long and winding road." 44 The importation of governance mechanisms from traditional businesses to microfinance would therefore be counterproductive. ${ }^{45}$

The microfinance sector merits a specific corporate governance framework when examined from a theoretical perspective. Traditional firms use corporate governance to mitigate agency costs through monitoring of agents by the principals or other third party reputational intermediaries. ${ }^{46}$ In view of the inability of the agency cost approach to address the relationship between financial sustainability and social goals, corporate governance issues in the microfinance industry must be subjected to a different set of parameters that effectively aim at the core of that relationship. Towards that end, I build upon a three-dimensional approach set out by Mersland and Strom ${ }^{47}$ in identifying problems that affect various constituencies within the microfinance sector from a corporate governance standpoint:

1. A Vertical Dimension between the MFI and its providers of capital, which include shareholders, financiers, and employees;

2. A Horizontal Dimension between the MFI and its customers and the communities that are affected by it; and

3. An External Dimension focusing on the market for product competition and the role of the state in regulating the sector.

A diagrammatic representation of the three-dimensional approach is set out in Figure 1.

${ }^{44}$ Marc Labie, Corporate Governance in Microfinance Organizations: A Long and Winding Road, 39 MGMT. DECISION 296 (2001).

${ }^{45}$ Roy Mersland \& R. Oystein Strom, Performance and Governance in Microfinance Institutions, $33 \mathrm{~J}$. BANKING FIN. 662, 668 (2009) [hereinafter Mersland \& Strom, Performance and Governance].

${ }^{46}$ Examples of reputational intermediaries include independent directors and auditors mandated for public listed companies in almost all leading jurisdictions. See JOHN C. COFFEE, JR., GATEKEEPERS: THE PROFESSIONS AND CORPORATE GOVERNANCE 7, 144 (2006).

${ }^{47}$ Mersland \& Strom, Performance and Governance, supra note 45. 
Microfinance and the Corporate Governance Conundrum

Fig. 1

Relationship-Dimensions in MFIs
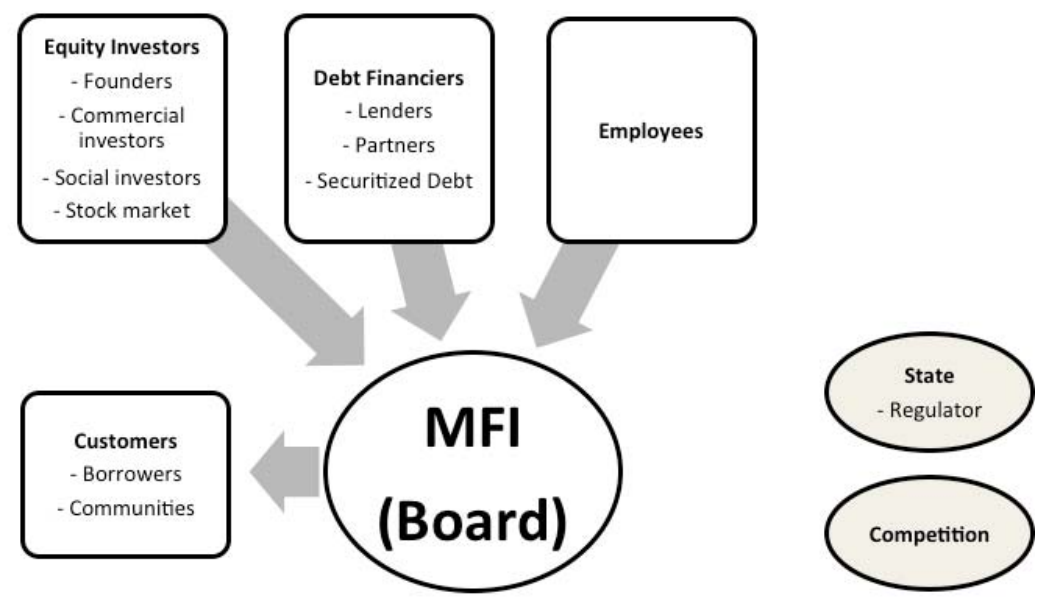

This choice of approach requires explanation. The vertical dimension considers the providers of capital to an MFI under one single category, and examines their relationship with the MFI (represented by its board and management). As far as shareholders are concerned, their position is similar to that in a traditional agency cost approach, whereby the board and management of the MFI are obligated to protect their interests. ${ }^{48}$ As we shall see, most shareholders focus on financial returns, although some of them do pay attention to social goals as well. As far as financiers and employees are concerned, conventional corporate governance framework includes them within the diverse category of stakeholders with arguably limited protection conferred by corporate law and governance mechanisms. ${ }^{49}$ However, when their interests are juxtaposed against the financial sustainability and outreach relationship, their interests are similar to shareholders because their interest lies principally in ensuring the financial sustainability of the MFI. This is because they have sunk in part or all of their fortunes in the form of debt or human capital into the MFI, and it is therefore in their self-interest to ensure the MFI is sufficiently

${ }^{48}$ For a detailed discussion on this agency problem in a company, see Michael Jensen \& William Meckling, Theory of the Firm: Managerial Behavior, Agency Costs and Ownership Structure, 3 J. FIN. ECON. 305 (1976).

49 See Paul L. Davies, The Board of Directors: Composition, Structure, Duties and Powers, Paper on Company Law Reform in OECD Countries: A Comparative Outlook of Current Trends (2000), available at http://www.oecd.org/dataoecd/21/30/1857291.pdf. 
profitable to provide adequate return on such capital. ${ }^{50}$

The horizontal dimension is designed to deal with the other side of the coin-outreach and the march toward achieving social goals. The key stakeholder is the group of customers of the MFI, represented by the poorer sections of the society (or the BoP). This dimension places emphasis on the need to protect the interests of the customers who do not have a direct voice in the MFI. A lack of homogeneity traditionally troubles the stakeholder approach in corporate governance, but these concerns do not find a place here. The stakeholders in the horizontal dimension are a clearly identifiable constituency ${ }^{51}$ While their interests as customers can be subject to greater measurement and evaluation, the same cannot be said about the impact of the MFI's activity on the broader communities, although empiricists have been constantly evolving proxies to measure such impact too.

The external dimension takes into account the effect of product market competition on the governance of MFIs. Although the natural effect of competition would be to reduce costs and prices thereby benefiting the customers, the microfinance industry has been drawn into a different trajectory that has plagued customers with problems of over-indebtedness due to information asymmetry. Similarly, the state, it is expected, will play an enabling role through regulation that makes cost-effective financial products and services available to BoP customers. However, the microfinance sector has been affected by duality problems where the state is a regulator as well as a player in the market through grant of subsidized credit to BoP customers. Hence, its regulatory policies may not be enabling in nature as they are afflicted by rent-seeking tendencies on the part of the state. ${ }^{52}$ The implications arising out of the external dimension cannot be ignored in the governance framework within an MFI.

After proposing the framework for analysis, the Article now discusses each of the specific dimensions and identifies incentives that operate with reference to each of the players in an MFI, and maps them along the financial sustainability—social impact continuum.

\section{THE VERTICAL DiMENSION}

This Part explores the relationship between the MFI and its capital providers. While the MFI itself is embodied in a corporate legal personality, its interests in this dimension are represented by its board of directors. ${ }^{53}$ In

\footnotetext{
${ }^{50}$ Of course, even with financiers and employees, there could indeed be some who are disposed towards broader social goals without limiting themselves to a myopic view in favor of financial returns.

${ }^{51}$ See infra Part VII(A).

${ }^{52}$ For a greater discussion of rent seeking by the state, see infra notes 173-176.

${ }^{53}$ This is consistent with general principles of corporate law where the board is the primary organ of the
} 
Microfinance and the Corporate Governance Conundrum

analyzing the vertical dimension, the Author hypothesizes that the principal interest of capital providers to a for-profit institution (such as an MFI) is the maximization of financial returns from the venture. Consequently, capital providers are likely to closely monitor the financial sustainability of the MFI, with the social goals playing a more subservient role.

\section{A. Equity Investors}

At the outset, it would be necessary to consider investors who provide share capital to the company. ${ }^{54}$ Shareholders, as the residual owners of the company, enjoy the largest share of returns in the company, but they also bear the highest amount of risk. They are also collectively able to control the company, including the composition of the board, and exercise their rights to vote on specific matters that are reserved for shareholder vote. The power of control and the ability to influence decision making within the MFI place them in a different position from the other capital providers.

The structure of investments and shareholding pattern in MFIs are at considerable variance from traditional businesses. The archetypal cycle followed by MFIs begins with its founders using minimal financial resources and aims and then proceeding to mature its business to arrive at the logical conclusion of a public offering of its stock enabling its listing on stock exchanges. ${ }^{55}$ Under this model, MFIs are founded by NGOs or socially-driven individuals, either of whom takes the position of the founder with some shareholding in the company. This may be accompanied by seed-funding infused by angel investors such as high net-worth individuals or even small investments by private equity firms. As the business matures, MFIs obtain larger amounts of capital through investments by conventional private equity firms and other social investors (such as specific investment funds established for social investing and development finance and multilateral organizations). The final phase involves a public offering and listing of securities. Although only a handful of MFIs have in fact completed this cycle, a vast number of them expect to do so ${ }^{56}$, subject to the existence of favorable market conditions.

company.

${ }^{54}$ In considering the position of shareholders, this Article makes no further distinction between types of shares held, such as equity shares or common stock on the one hand and preference shares or preferred stock on the other hand. Terms of these types of shares vary across jurisdictions. Regardless of the type, the important feature of the shares for this purpose is the residual nature of the ownership and the resulting control rights provided to the holders thereof.

55 Sriram, Commercialisation of Microfinance in India, supra note 17, at 66-67; Gil Crawford \& Lauren Clark, Capital Markets: A Long-Term Solution to Financial Freedom, 10 MiCROENTERPRISE DEVELOPMENT REVIEW 2, 3 (2007). While MFIs usually commence operations as NGOs and then convert to commercial enterprises, other business may commence on a for-profit basis from the outset.

56 See Rina Chandran, Profiting from poverty? Microfinance IPO sparks debate, REUTERS (Apr. 9, 2010), available at http://www.reuters.com/article/2010/04/09/us-microfinance-india-ipo-analysisidUSTRE63814G20100409, ("With about half a dozen big Indian MFIs contemplating IPOs, SKS' 
To be sure, this is not the only model used to carry on microfinance activities on a commercial basis. Indeed, several existing commercial banks (both government-owned and privately owned) have forayed into the microfinance business on a large scale. ${ }^{57}$ For these banks, microfinance is yet another business activity and it is hard to extract evidence of social goals at an institutional level. ${ }^{58}$ Moreover, such commercial banks would be subject to the general framework of corporate governance as the trade-off between financial sustainability and social goals may not be as pronounced..$^{59}$

Returning to stand-alone MFIs, which are the focus of this Article, a striking feature of investors is their diversity, not only in terms of their financial outlook, but also for their social goals. While such a "mixed profile"60 is likely to move the organization toward marrying both the objectives, it portends a serious risk of incoherence in its policies and lack of a clear direction.

With this background, the Article now moves to analyze the roles of the different types of equity investors in the governance of MFIs. A discussion of types of equity investors is critical in determining the role of the board of an MFI that is comprised of investor representatives. Their respective motivations to invest in MFIs will shape the company's approach towards balancing financial sustainability and social impact.

\section{Founders}

Two broad patterns can be observed in the formation of for-profit institutions in the microfinance industry. The type of founding investors varies according to the formation-type. The first is "greenfield MFIs" founded by socially-minded individuals hitherto employed as professionals, usually in the banking or finance industry. The second is "transformed MFIs" that have come into existence by taking over the microfinance business hitherto carried out by an NGO.

Certain features of the greenfield MFI founders induce a tendency in them to closely monitor financial sustainability. The founders of greenfield MFIs

offering will be a milestone, the JPMorgan/CGAP report said ....”).

${ }^{57}$ For example, multinational banks such as Citibank and Deutsche Bank have ventured into the microfinance business as a profitable business opportunity. See Tim Harford, The Battle for the Soul of Microfinance, FIN. TIMES (Dec. 6, 2008); Asad Mahmood, Reality of Social Investments: There Ought to be More Direct and Proactive Investments with Deeper Social Impact, 10 MICROENTERPRISE DEV. REv. 13 (2007); see also Rachel Rock, Maria Otero \& Sonia Saltzman, Microenterprise Best Practices, Principles and Practices of Microfinance Governance, DAI/USAID (1998), available at http://www.uncdf.org/mfdl/readings/MFGovernance.pdf.

${ }^{58}$ It is true, though, that individuals within commercial banks spearheading the microfinance business may have had a background in the social sector or may otherwise possess a socially-minded outlook. See Mahmood, supra note 57; Harford, supra note 57.

${ }^{59}$ In the context of such commercial banks, it has been noted that "we are generally looking at the

'classic' type of shareholders; essentially profit-driven.” Labie, supra note 44, at 297.

${ }^{60} I d$. 
draw from their professional background, having worked in large business organizations with stringent systems and practices. Moreover, since the microfinance activity is at its nascent stages in such companies, tighter monetary controls accompanied by restrictive lending practices may mean lesser emphasis on outreach. Nevertheless, greenfield MFI founders do maintain steady focus on social impact given that one of the principal reasons they have embarked on such a venture is to give vent to their social and philanthropic outlook.

The more prominent method of establishing MFIs is through the process of transformation of existing businesses of NGOs into corporate entities. Such transformation is occasioned due to the inability of NGOs to easily access the equity (or even debt) that is required to finance their business. Corporatizing the microfinance business in the form of an MFI would commercialize the activity and achieve scalability by obtaining access to market-based sources of funding. Upon transfer of the business to the MFI, the NGO would obtain shareholding in the MFI. ${ }^{61}$ It is possible that key individuals within the NGO would also obtain a small amount of personal shareholding in the MFI. Due to their background in managing a microfinance $\mathrm{NGO},{ }^{62}$ founders of transformed MFIs do maintain emphasis on social goals and outreach. ${ }^{63}$ Due to their commitment for the cause, founders are long-term investors in MFIs. ${ }^{64}$ From their perspective, the compulsion to commercialize and transform was driven by the need for additional capital (as opposed to making profits).

While the founders' role at the initial stages is substantial in defining the MFI's mission, the need for additional capital results in a dilution of their shareholding in the company. For this reason, the founders' shareholding dwindles to a minority stake once other financial investors buy in. ${ }^{65}$ From the single voice of the company, their goals are arguably tempered once other

${ }^{61}$ In India, which has witnessed a number of such cases of transformation, there are additional issues arising out of transformation of NGOs into MFIs. Since NGOs are not permitted to hold shares in a company, several thousand BoP customers were provided funds by the NGOs, which were in turn aggregated into mutual benefit trusts (MBTs) that invested in shares of the MFI. Although this was an indirect method, the NGOs or their key officers were able to maintain adequate control over the MBTs and thereby their shareholding in the MFIs. The use of the MBTs and specific governance issues that arise from it are the subject matter of discussion and critique in Sriram, Commercialisation of Microfinance in India, supra note 17.

${ }^{62}$ NGOs are generally "public purpose" organizations that obtain donor funding with no residuals claims over income or assets. Providers of either financial capital or human capital therefore do not expect to profit from the activity of the NGO. Social impact is the sole goal. See Sriram, Commercialisation of Microfinance in India, supra note 17, at 66.

${ }^{63}$ Rock, Otero \& Saltzman, Microenterprise Best Practices, supra note 57, at 24.

${ }^{64} \mathrm{Id}$.

${ }^{65}$ Although in most cases the founders and managers hold only a minority stake in the company, which results in the classic situation of separation of ownership and control, there are high profile exceptions where founders continue to hold a substantial equity stake in mature MFIs. See Labie, supra note 44, at 299. 
equity investors gain a foothold.

\section{Commercial Investors}

One of the principal reasons for transformation of MFIs is the ability to raise commercial capital. Institutional investors such as a private equity funds and venture capital firms infuse capital into portfolio companies using the proceeds of fund-raising activities from their own investors. ${ }^{66}$ These institutional investors are managed by professional fund managers who are experienced in the financial markets. ${ }^{67}$ Although the microfinance sector initially received funding from social investors and developmental institutions, it is now obtaining significant attention from the commercial institutional investors. ${ }^{68}$ Matters have progressed to such an extent that the institutional investor community has begun to recognize microfinance as a separate asset class with an attractive commercial investment opportunity. ${ }^{69}$

Institutional investors are advantageous to MFIs because they not only address initial funding requirements, but can be relied upon to provide ongoing funding in the form of additional capital. Moreover, with their professional investment outlook, institutional investors are able to inculcate a greater sense of financial discipline and controls within the MFI organization, which may suffer from inadequacies due to its prior operation in the form of an NGO. They are also able to provide technical and strategic inputs to management that allows for greater innovation. Such investors are also committed to the company for a longer term as their investment is made at a time when the MFI is not publicly listed thereby leaving them with less liquidity in the company.

In terms of expectations for the MFI business, institutional investors are largely driven toward financial returns. They view microfinance as yet another investment opportunity. As one observer notes: "Institutional investors are

${ }^{66}$ Arpita Amarnani \& Neeraj Amarnani, Venture Capital Funds for Microfinance in India (Nirma Univ. J. Bus. \& Mgmt. Studies, 2010), available at http://ssrn.com/abstract=1715816.

${ }^{67}$ Patrick Goodman, Microfinance Investment Funds: Objectives, Players, Potential in INGRID MATTHAUS-MAIER \& J.D. VON PISCHKE (EDS.), MiCROFINANCE INVESTMENT FUNDS: LEVERAGING PRIVATE CAPITAL FOR ECONOMIC GROWTH AND POVERTY REDUCTION 14 (Ingrid Matthaus-Maier \& J.D. von Pischke eds., 2006).

${ }^{68}$ Id. at 25. See also William Langer, The Role of Private Sector Investment in International Microfinance and the Implications of Domestic Regulatory Environments, 5 B.Y.U. INT’L L. \& MGMT. REV. 1, 4 (2008) (finding that "private commercial investment in microfinance began to grow at annual rates approximating $50 \%$ in the year 2000, reaching an estimated total of $\$ 2$ billion invested by the end of 2006. Private investment is expected to gradually overtake funding from non-commercial and public sources.”).

${ }^{69}$ Marc de Sousa-Shields, Commercial Investment in Microfinance: A Class by Itself? in MATTHAUsMAIER \& VON PISCHKEMICROFINANCE INVESTMENT FUnDS, supra note 67, at 82; Crawford \& Clark, supra note 55, at 1, 2. Srinivasan notes: "A poll of 50 investment banking firms/companies brought out that microfinance is the top ranked destination for investments in the financial sector today. Of those who voted, more than 80 per cent rated microfinance as the best sector for investments." Srinivasan, supra note 26 , at 31 . 
Microfinance and the Corporate Governance Conundrum

under extreme performance pressure and usually have limited understanding of microfinance." ${ }^{70}$ The profit orientation of commercial institutional investors is fortified by their own organizational structure. For instance, fund managers are under pressure to provide consistent returns so they can return to the markets to raise further capital on the strength of their past performance. Moreover, the typical fund structure established for institutional investors prompts a profitoriented approach due to its specific incentive structures. ${ }^{71}$ Of importance is the compensation payable to the fund manager, which typically follows the "two and twenty rule". ${ }^{72}$ Under this method, fund managers are paid a management fee of approximately two percent of the institution's capitalization, and in addition a percentage, customarily twenty five percent, of the institution's profits, known in the industry as "carry."73 Although the logic of the carry is to align the interests of the fund manager and investors, it not only enhances the profit motive of the fund managers, but even predisposes them to indulge in risky investments with a view to generate accelerated returns. ${ }^{74}$

While the growth of private equity and venture capital investment into MFIs has witnessed the induction of greater professionalization of the sector, there is also a marked emphasis on profit generation and financial sustainability and much less on the social impact of MFIs.

\section{Social Investors}

Along with increased participation by commercial investors in the microfinance industry, there has also been a significant growth in the number and size of socially oriented institutional investors. ${ }^{75}$ These social investors seek to counterbalance the effect of commercialization (and the consequent diminution in social objectives) by placing importance on the social impact of microfinance. They maintain a balance between financial sustainability and social impact without necessarily preferring either over the other, i.e. the classic "win-win" situation. They do so as part of their stated mission as well as by monitoring the performance of their investments, which are concentrated in

\footnotetext{
${ }^{70}$ Goodman, supra note 67, at 24.

${ }^{71}$ On a related note, it is well-known that institutional investment suffers from a two-level agency cost problem. The first operates between the institution (principal) and its portfolio company, being the MFI (agent) and the second between the investors in the institution (principal) and the fund manager (agent). See Labie, supra note 44, at 297.

${ }^{72}$ Victor Fleischer, Two and Twenty: Taxing Partnership Profits in Private Equity Funds, 83 N.Y.U. L. REV. 1 (2008).

${ }^{73}$ Lee Harris, A Critical Theory of Private Equity, 35 DEL. J. CORP. L. 259, 283 (2010); Ronald Masulis \& Randall S. Thomas, Does Private Equity Create Wealth? The Effects of Private Equity and Derivatives on Corporate Governance, 76 U. CHI. L. REV. 219, 222-23 (2009).

${ }^{74}$ Id. See also Ronald J. Gilson, Engineering a Venture Capital Market: Lessons from the American Experience, 55 STAN. L. REV. 1067, 1089 (2003).

${ }^{75}$ Goodman, supra note 67, at 11.
} 
microfinance and other social businesses.

Social investors tend to be of two types. The first is represented by the commercial arms of multilateral institutions or other development agencies. ${ }^{76}$ In addition, foundations and NGO also perform the role of social investors seeking mixed commercial and social goals. ${ }^{77}$ These institutions possess a rich background of providing financial assistance in the developmental and social sectors.

The second type of social investors is represented by specific institutions established for the purpose of investing in social businesses. ${ }^{78}$ More specifically, there has been a strong emergence of sector-specific microfinance investment funds (MFIFs) ${ }^{79}$ The MFIFs are sponsored by development agencies, NGOs, and increasingly by commercial financial institutions. ${ }^{80}$ These MFIFs have a variety of investors, ranging from wealthy individuals such as entrepreneurs and philanthropists, development agencies, foundations, NGOs, and commercial institutional investors. ${ }^{81}$ In terms of fund structures, MFIFs follow the same pattern as commercial institutional investors, and they are bound by the customary fiduciary duties owed to investors and also by applicable securities laws depending on their domicile. ${ }^{82}$

A distinct advantage of social investment in the microfinance sector is that it is tailored toward both financial as well as social objectives. Even though financial sustainability is an important concern, it is not the sole criterion as for commercial investors. Social investors pursue other objectives such as outreach and the impact of microfinance activity on the communities it serves. The difficulty, however, is the "lack of performance valuation and presentation standards [that] makes it virtually impossible for investors to compare funds by their risks and rewards." ${ }^{83}$ Although standards for financial sustainability are well-established, social impact is difficult to measure, and there continues to be

${ }^{76}$ Some of the key examples of this type are the International Finance Corporation (IFC), KfW (Germany) and the Multilateral Investment Fund of the Inter-American Development Bank. Goodman, supra note 67 at 21.

${ }^{77}$ Investors of this nature are Rabobank Foundation and Unitus. Id.

${ }^{78}$ This is consistent with the prominence of the related concept of "socially responsible investing," which "has developed to identify and invest in firms acting in socially and environmentally responsible ways.” M. Todd Henderson \& Anup Malani, Corporate Philanthropy and the Market for Altruism, 109 COLUM. L. REV. 571 (2009). Microfinance provides an excellent avenue for socially responsible investing. See Jed Emerson, Steady Returns With Social Impact, FORBES, Sep. 29, 2009, available at http://www.forbes.com/2009/09/29/emerson-calvert-sri-intelligent-investing-impact-investing.html.

${ }^{79}$ It is estimated that in 2007 there were about eighty-five MFIFs holding an investment of about \$3.2 billion in the microfinance sector. Langer, supra note 68 , at 5 .

${ }^{80} \mathrm{Id}$. at 19.

${ }^{81} I d$. at $21-25$.

82 de Sousa-Shields, supra note 69, at 91.

${ }^{83}$ Robert Pouliot, Governance, Transparency, and Accountability in the Microfinance Investment Fund Industry, MATTHAUS-MAIER \& VON PISCHKE, supra note 67, at 148. 
Microfinance and the Corporate Governance Conundrum

debates about whether it can be measured at all. ${ }^{84}$ One possibility might be to judge the social performance of each MFIF against its stated mission in the securities offering documents. While that can operate as a proxy, the inherent subjectivity of measuring social impact makes judging social performance an onerous task.

\section{Investors in the Capital Markets}

The final phase in the financial evolution of an MFI is a public offering of securities, which are then listed on stock exchanges. It makes the MFI's stock available for trading in the capital markets. The listing of Compartamos in 2007 in Mexico, and that of SKS Microfinance in 2010 in India have evoked tremendous investor response indicating the maturity of the sector. ${ }^{85}$ These offerings raised several hundred million dollars each commanding a huge premium, ${ }^{86}$ but they have also attracted criticism that it enables players in stock markets to profit from the poor. ${ }^{87}$

Listing of an MFI carries with it certain advantages. ${ }^{88}$ The liquidity of the stock provides avenues to raise further capital at reduced costs. It provides greater credibility and profile not only in the financial markets, but also in the product markets and with regulators. An MFI can use its listed stock to reward and incentivize employees through stock options, and also use the stock as currency for acquisitions (although there is no evidence yet of a robust market for mergers and acquisitions in the microfinance industry). A listed MFI is subjected to greater standards of corporate governance. ${ }^{89}$ However, listing is also accompanied by significant costs and challenges. ${ }^{90}$ Listed MFIs are

\footnotetext{
${ }^{84}$ Moreover, it is usually the case that social investors "are looking at social investments by the same measures they are using to judge very development commercial markets. They want these assets to be rated and liquid with daily price quotes. You can not have it all ....” Mahmood, supra note 57, at 18.

${ }^{85}$ Although these offerings were preceded by two other MFI offerings, one by Bank Rakyat Indonesia in 2003, and the other by Equity Bank, Kenya in 2006, the previous offerings were not as high-profile and did not attract as much attention and debate. Rhyne \& Guimon, supra note 23, at 13.

${ }^{86}$ The Compartamos offering raised a total of US\$ 468 million from 5,920 investors both within and outside Mexico. Id. at 1 . The SKS offering raised US\$ 358 million in an offering that was oversubscribed 13.7 times (primarily through institutional investor interest). Srinivasan, supra note 26, at 57.

${ }^{87}$ See supra, note 24 , and accompanying text. See also, Schmidt, supra note 7.

${ }^{88}$ These advantages are generally similar to the listing of any other business. For a general discussion of the advantages of listing, see Lynn A. Stout, The Unimportance of Being Efficient: An Economic Analysis of Stock Market Pricing and Securities Regulation, 87 MiCH. L. REV. 613, 662-63 (1988).

${ }^{89}$ For a general discussion on the correlation between listing of securities and corporate governance, see John C. Coffee, The Future as History: The Prospects for Global Convergence in Corporate Governance and its Implications, 93 Nw. U. L. Rev. 641 (1999); Amir N. Licht, Legal Plug-ins: Cultural Distance, Cross-Listing, and Corporate Governance Reform, 22 BERKELEY J. INT’L L. 195 (2004).

${ }^{90}$ William J. Carney, The Costs of Being Public After Sarbanes-Oxley: The Irony of "Going Private," 55 EMORY L. J. 141 (2006); Dale A. Oesterle, The High Cost of IPOs Depresses Venture Capital in the United States, 1 ENTREPRENEURIAL BUS. L.J. 369 (2007).
} 
required to incur compliance costs as well as opportunity costs in terms of senior management time in ensuring compliance with a plethora of additional corporate and securities legislation that become applicable as a result of listing. In addition to these general costs of listing, the microfinance sector raises a specific concern: could the capital markets orientation of listed MFIs drive them toward greater profitability at the cost of social concerns?

This Article argues that despite a strong social orientation of the organization and its founder, an MFI that submits itself to the domain of capital markets is vulnerable to serious mission drift due to the manner in which capital markets and investors operate within the existing paradigm. There are a number of reasons for this drift.

First, the anonymity of the stock markets makes it impossible to control or even identify the goals of investors. ${ }^{91}$ For example, the nature of liquid stock markets is such that MFIs cannot restrict investments only to investors with at least some social goals. Commercial investors with an eye on profitability will likely crowd out social investors. While an MFI can continue to balance commercial and social investment in a private situation, it will have to relinquish such ability once it chooses to list its securities. Pressures of performance of stock price therefore drive a publicly listed MFI toward the commercial end of the spectrum.

Second, liquidity and an open market for trading in securities of MFIs leave it vulnerable to adoption of equity positions by short-term investors. The phenomenon of short-termism in the stock markets is signified by investors moving in and out of the markets within a short span of time with the sole purpose of deriving financial returns based on market-movements. ${ }^{92}$ Although gains through trading in stocks are made out of the stock markets and not necessarily from the MFI or its BoP customers, they may attract a larger number of commercial investors than social investors. Moreover, it raises ethical concerns about whether short-term market investors must be allowed to profit out of such investments where MFIs may be compelled to adopt a commercial approach to appease investors at the cost of social goals. For instance, short-termism has been criticized for turning managements' focus toward short-term performance quarter-on-quarter by making quick profits and deviating their attention from more long-term goals. ${ }^{93}$ As far as the

\footnotetext{
${ }^{91}$ Chris Brummer, Stock Exchanges and the New Markets for Securities Laws, 75 U. CHI. L. REV. 1435, 1463 (2008); Jonathan R. Macey \& Maureen O'Hara, From Markets to Venues: Securities Regulation in an Evolving World, 58 STAN. L. REV. 563, 569 (2005).

${ }^{92}$ See Nadelle Grossman, Turning a Short-Term Fling into a Long-Term Commitment: Board Duties in a New Era, 43 U. MiCH. J.L. REFORM 905 (2010).

${ }^{93}$ Martin Lipton \& Steven A. Rosenblum, Election Contests in the Company's Proxy: An Idea Whose Time Has Not Come, 59 Bus. Law. 67, 78 (2003); William W. Bratton, Enron and the Dark Side of Shareholder Value, 76 TUL. L. REV. 1275, 1284 (2002).
} 
Microfinance and the Corporate Governance Conundrum

microfinance sector is concerned, the gestation period for social impact is longterm in nature, while financial sustainability may involve a shorter term. Such MFIs and their managements will be bound by day-to-day performance of stock markets, which is more tangible in nature, than the longer-term view on social performance. Stock markets will punish a drop in short-term financial performance, while failure to attain social impact will go relatively unnoticed. While short-termism generated by stock market behavior is generally under attack, it must apply with greater ferocity in the MFI sector which came into being in the first place to create social impact and address the problems of poverty.

Third, and related to the issue of short-termism, MFI investments become the subject matter of speculative activity. Stocks may witness rapid fluctuations within a short span of time, as amplified by the steep fall in stock price in the months following the high-profile listing of SKS Microfinance, as set out in Figure 2. Such fluctuations enable speculators and arbitrageurs to make quick profits on this count. Unsurprisingly, instances of speculative activity have been witnessed on MFI counters as well. ${ }^{94}$ Stocks are also susceptible to short selling by market participants intending to make a quick profit, and also to insider trading and market manipulation that are usually proscribed by the law. These not only take away the attention of management from activities that bring about serious social impact, but they tend to raise concerns about the credibility and image of the microfinance sector not just among their donors, investors and customers, but more importantly with the government and its regulators.

${ }^{94}$ For example, a sharp decline of the SKS Microfinance stock during two days in May 2011 has been attributed to either a "possible breach of insider trading norms or the involvement of a bear cartel." Viswanatha Pilla, SKS shares tumble; firm says will welcome regulatory probe, THE MINT (May 9, 2011). 
Fig. 2

\section{Performance of SKS Microfinance's Stock Post-Listing ${ }^{95}$}

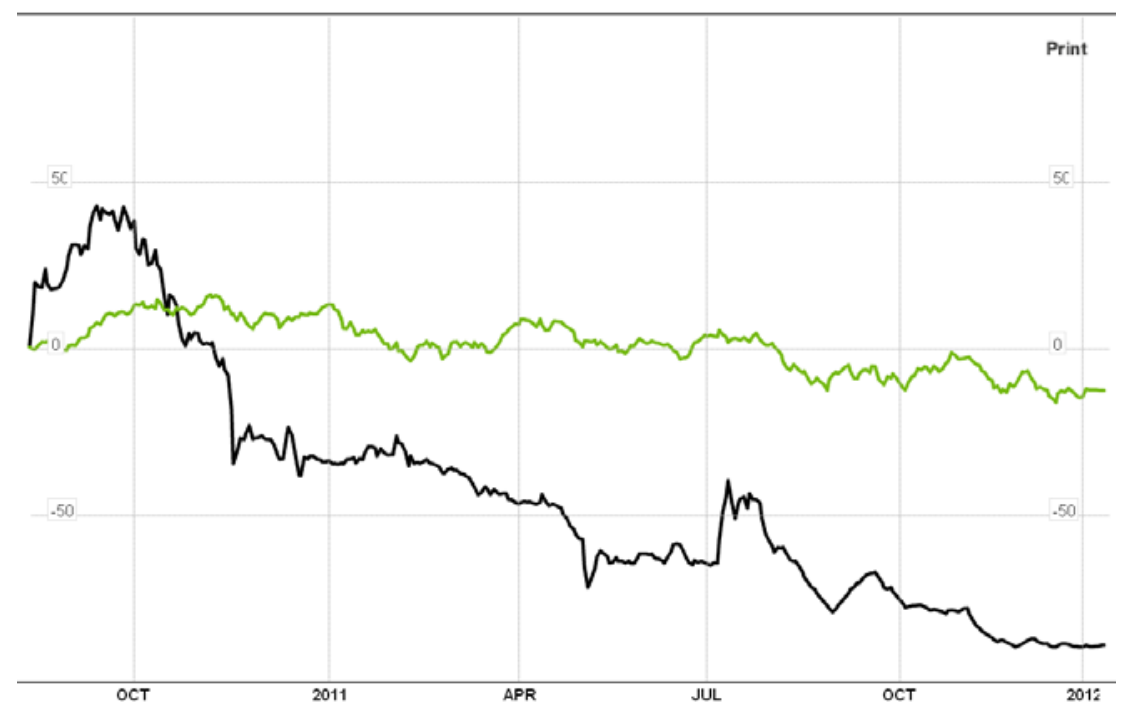

In sum, all equity investors (with the exception of some founders and social investors) are invested in MFIs in order to obtain financial returns just the same way they invest in other commercial businesses. Profit motive appears to be the principal goal, and even if they possess any shade of social objectives they are only secondary in nature. The return-seeking incentives of commercial investors in MFIs will likely drive management toward ensuring financial sustainability even if that comes at the cost of possible social impact.

\section{B. Financiers}

Apart from equity funding, MFIs raise finances through borrowings from lenders that are either banks or public financial institutions. MFIs also enter into off-balance sheet arrangements with such lenders. These include the partnership model and securitization of microfinance debt. Although these are not strictly credit arrangements as far as MFIs are concerned, they nevertheless

\footnotetext{
95 Source: BLOOMBERG MARKET DATA, http://www.bloomberg.com/quote/SKSM:IN/chart (last visited Jan. 11, 2012). Figure 2 is a comparison of the monthly stock price of SKS Microfinance (charted in bold) in the months following its listing and the monthly values of two key Indian stock indices, the BSE Sensex and the NSE Nifty (charted in the lighter color) during the same period.
} 
Microfinance and the Corporate Governance Conundrum

provide financing to MFIs. More importantly, all of these arrangements facilitate the financial sustainability objectives of MFIs, as we shall now see with respect to each type of financing.

\section{Borrowing}

MFIs obtain financing from traditional commercial banks. The borrowing is through bilateral loan agreements, syndicated loan arrangements as well as bond issuances to investors. ${ }^{96}$ Commercial banks, especially those owned or controlled by the government, have evinced interest in the microfinance sector both for financial returns as well as social impact. For instance, the self-help group (SHG)-bank linkage program has been hugely successful in India, ${ }^{97}$ although the program preceded the commercialization of the microfinance sector through the emergence of for-profit institutions.

Commercial banks have also been keen on lending to the microfinance sector as they are able to utilize it to fulfill sector-based lending requirements to underprivileged borrowers as mandated by banking regulation. Looking at India again, the Reserve Bank of India (RBI) requires all commercial banks to satisfy "priority sector lending" requirements by which they are required to lend to priority sectors such as rural customers and agricultural activities. ${ }^{98}$ The RBI accepted lending to MFIs as satisfying priority sector requirements, and this went on to provide tremendous supply of loans to MFIs. More recently, however, the motivations of commercial banks to lend to MFIs have undergone a change. Banks find lending to microfinance activity a commercially attractive proposition..$^{99}$ In other words, banks are in the microfinance lending business to add to their bottom lines. From the perspective of the MFIs, therefore, they need to demonstrate acceptable levels of financial performance and minimal risk before obtaining loans from commercial banks. ${ }^{100}$ That will lead MFI managements to closely monitor financial sustainability to be in a position to

${ }^{96}$ Goodman, supra note 67, at 32; Langer, supra note 68, at 12, 15.

${ }^{97}$ See Franklin Allen, Rajesh Chakrabarti \& Sankar De, India's Financial System, Oct. 27, 2007, at 50, available at http://ssrn.com/abstract=1261244; see also MEERA LAL, SHB-BANK LINKAGE IN INDIA: EMPOWERMENT AND SUSTAINABILITY (2007).

${ }^{98}$ Tara Nair, M.S. Sriram \& Vishwanath Prasad, ICICI Bank, India in SMALl CustomER, Big MARKET: COMMERCial BANKS IN MicROFINANCE 105 (Malcolm Harper \& Arora Sukhwinder Singh ed., 2004); Scott Gaul, How Has the Growth of Indian Microfinance Been Funded?, MicroBANKING Bulletin (Dec. 2010), available at http://www.themix.org/publications/microbanking-bulletin/2010/12/how-hasgrowth-indian-microfinance-been-funded.

${ }^{99}$ Id. See also Harford, supra note 57.

${ }^{100}$ An instance of stringent conditions imposed by commercial banks on MFI lending relates to the fact that such banks not only impose tight requirements on debt-to-equity ratios but also seek collateral and guarantees from founders of MFIs. This poses difficulty because founders tend to be social entrepreneurs with limited holdings of assets. Founders are therefore compelled to ensure profitability and financial sustainability to ensure that obligations under loan arrangements are met in a timely manner. Social equity is entirely ignored in this process. See Srinivasan, supra note 26, at 56. 
raise debt finances when required.

The financial sustainability approach of borrowing from banks is also reinforced in a related scenario. Commercial banks do not hesitate to curb the flow of funds to the microfinance sector if financial sustainability is at risk. Recent instances show that commercial banks have cut off funds to the sector during the global financial crisis, and more severely in India where the microfinance industry is undergoing turmoil since late 2010. ${ }^{101}$ Many commercial banks have ceased loans to MFIs operating in the State of Andhra Pradesh. They are also attempting to restructure existing loan portfolios, signaling behavior that is entirely consistent with pure commercial lending. ${ }^{102}$ The commercial lending community appears to be adopting similar approaches toward the microfinance sector with social goals and the for-profit commercial ventures.

\section{Partnership Model}

Under this model, the MFIs perform the role of an intermediary and they facilitate the lending of monies by commercial banks directly to BoP customers. ${ }^{103}$ MFIs as intermediaries provide "loan origination, monitoring and collection services, for a fee." 104 This model has been structured to free some of the MFIs' capital constraints, which "allows them to achieve rapid increase in outreach." 105 MFIs are suitably placed to perform the role of an intermediary because of their presence and outreach in the BoP space along with relationships they have built with customers over a number of years.

Although the partnership model enables MFIs to focus their own direct lending to create social impact, this model too places greater emphasis on profit generation for the commercial banks and less on social impact. The commercial banks have a direct relationship with the BoP customer, and the MFIs act only as an agent. They are not in a position to influence the strategic goals of the bank. Furthermore, the MFIs may also be required to bear a portion of the risk of the commercial bank's lending. ${ }^{106}$ This financial risk-sharing arrangement is structured to provide incentives to the MFIs to ensure smooth collection of debts from BoP customers. That in turn imposes pressure on MFI managements

${ }^{101}$ Lydia Polgreen \& Vikas Bajaj, India Microcredit Faces Collapse From Defaults, N.Y. TiMES (Nov. 18, 2010); Anajana Chandramouly \& K. Ramkumar, MFIs May Find the Going Tough as Fund Tap Runs Dry, Hindu Bus. Line (Apr. 10, 2011).

${ }^{102}$ Dinesh Unnikrishnan, Microfinance Firms' Loan Recast Hits a Roadblock, THE MiNT (Apr. 6, 2011); Somasroy Chakraborty, Banks Quarrel Over MFI Debt Recast, Bus. STANDARD (Apr. 13, 2011).

${ }^{103}$ See Malcolm Harper \& Marie Kirsten, ICICI Bank Partnership Linkages in India in EXPANDING THE

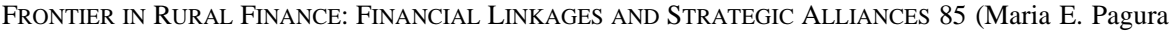
ed., 2008).

${ }^{104}$ Allen, Chakrabarti \& De, supra note 97, at 53.

${ }^{105}$ Nair, Sriram \& Prasad, supra note 98, at 110.

${ }^{106} \mathrm{Id}$. 
Microfinance and the Corporate Governance Conundrum

to tighten collection mechanisms, an act that may result in distancing themselves from social goals.

\section{Securitization}

Securitization has acquired popularity as a form of financing for MFIs. However, as discussed below, this instrument is not only accompanied by additional financial risks to MFIs, but could also dilute their focus on the social impact of their operations.

Since 2003-2004, MFIs have been raising finances using securitization mechanisms. ${ }^{107}$ The advantage of such off-balance sheet financing is that it provides liquidity to grant further loans to BoP customers and also rids MFIs of capital constraints. There are several transaction structures adopted to achieve off-balance sheet treatment for existing loans of MFIs. The more straightforward transaction involves the outright purchase by a commercial bank of an MFI's loan assets in return for purchase consideration. ${ }^{108}$ The loans are removed from the books of the MFI and they then belong to the commercial banks.

The other, and more customary, form of securitization transaction is the sale by MFIs of their loan portfolios to special purpose vehicles (SPVs) that in turn package these loan assets into securities in a tradable form that are usually issued to institutional investors on a private basis. This is particularly attractive in raising finances as it spreads the risk of investment among several investors. ${ }^{109}$ Securitization of a portfolio of loans of several MFIs will help raising significant finances for the microfinance sector, thereby enabling scaling up and effective outreach within a short timeframe. ${ }^{110}$

Experience from the global financial crisis, however, suggests that securitization is fraught with great risks. Several inadequacies of the securitization process involving sub-prime loans and mortgages have been exposed. ${ }^{111}$ One of the key features that led to failure is the very nature of subprime loans and subprime lenders. High interest rate loans were granted to high-risk borrowers, and the model placed reliance wholly on the fact that property prices would appreciate thereby mitigating the risk to lenders. ${ }^{112}$ At a

\footnotetext{
${ }^{107}$ Langer, supra note 68, at 13-14. For a detailed analysis of the benefits and costs of securitization in the context of microfinance loans, see Steven L. Schwarcz, Disintermediating Avarice: A Legal Framework for Commercially Sustainable Microfinance, 2011 U. ILL. L. REv. 1165 (2011); Steven L. Schwarcz, Helping Microfinance Become Commercially Sustainable, 46 GoNZ. L. REV. 495 (2011).

${ }^{108}$ Nair, Sriram \& Prasad, supra note 98, at 109.

${ }^{109}$ Langer, supra note 68, at 13.

${ }^{110}$ See id.

${ }^{111}$ For a succinct analysis of the problems leading from securitization of subprime loans, see Steven L. Schwarcz, The Future of Securitization, 41 CoNN. L. REv. 1313 (2009).

${ }^{112}$ Id. at 1317.
} 
broad level, there are similarities between subprime borrowers and microfinance borrowers that make lenders and investors of securitized paper in the microfinance industry equally vulnerable to repayment risk. MFIs almost always grant loans without any collateral, primarily because BoP borrowers do not possess any assets of value that can be secured. Microfinance loans therefore carry a significant risk of non-repayment. Although BoP customers in general display a stellar track record of repayment of microfinance loans, there could be various circumstances in which mass defaults in repayments occur. ${ }^{113}$ Securitization of microfinance loans may also suffer from the same defects in securitization of subprime crisis that were discovered following the global financial crisis. These include the moral hazard problem on the part of the MFIs ${ }^{114}$ and the information asymmetry, which leaves investors of securitized MFI debts at substantial risk.

Apart from the general risk of securitization to the investing community, securitization aggravates some of the problems of commercialization of microfinance, especially the lack of focus on social impact. The securitization process effectively passes the risk of microfinance loans from the MFIs to the investors. That creates acute problems in dealing with the issues of financial sustainability and social impact. Even assuming that the MFIs operate with a clear "win-win" strategy of maintaining financial sustainability along with creating social impact, they lose control over BoP customer strategy when the loans are securitized. Once investors become owners of the MFIs' loans (in a packaged form), they and their managers determine strategies for recovery. With the exception of any social investors who may have taken up securitized paper, other investors are invested in it solely for the financial returns. Therefore, a serious mismatch is likely to creep in between the goals and objectives of the MFI that originated the loans, and the investors who thereafter

${ }^{113}$ MFIs in the State of Andhra Pradesh in India have been witnessing such mass defaults during the 2010-2011 period, although that was primarily a result of legislation introduced by the State Government. It has been alleged that the crisis has been occasioned due to the political motives of the State Government rather than the inability or unwillingness of BoP customers to meet their repayment obligations in a timely manner. For a more detailed discussion of the political motives that triggered the Andhra Pradesh crisis, see infra notes 173-176, and accompanying text. Professor Schwarcz highlights a variant of the problem, which also stems from political interference in the lending and securitization process:

The subprime crisis also teaches us the danger of mixing politics and finance. Before the crisis, there was political pressure to securitize risky subprime mortgage loans to facilitate financing for the poor. We might see the same type of future political pressure, for example, to securitize risky microfinance loans to facilitate financing for the poor and disadvantaged.

Schwarcz, supra note 111 , at 1318.

${ }^{114}$ In the case MFIs are allowed to securitize loans soon after they are originated, a moral hazard is created as the MFIs do not assume the risk of defaulting loans once they are securitized. Schwarcz, supra note 111, at 1318-19. This point has also been endorsed by microfinance industry observers. See Srinivasan, supra note 26, at 56 (stating that "the concerns of the regulator have to be seen from the light of sub-prime problems where originators and investors tended to hold assets for very short periods of time and tried to shift risk elsewhere.”). 
Microfinance and the Corporate Governance Conundrum

become owners of those very same loan assets (and are then capable of determining the manner and extent to which repayments can be enforced). Investors are likely to demand repayment of the loans in order to meet their own returns from the investment, without having any regard to the plight of the BoP customers. ${ }^{115}$ The anonymity of the investors to the BoP customers causes a serious rift in understanding and appreciation of the social issues involved in microfinance. Even where the originating MFI may be involved in servicing the loan, it is unable to make any strategic decisions regarding the loans, all of which are handed over to the investors or their agents in the securitization process. Such decisions may include forgiveness of the loan in exceptional circumstances, or granting a moratorium, and the like. ${ }^{116}$

In sum, securitization is a useful instrument for MFIs to obtain financing and to remove capital constraints to achieve greater outreach. At the same time, the inherent structure of securitization seriously distorts the goals and missions of microfinance lending, as it directly replaces the MFI's outlook with that of the investors. If such investors are commercially oriented, as they mostly are, any social orientation of the MFI in terms of its mission will be eroded completed in favor of commercial returns. Social impact will have to give way entirely to financial sustainability.

\section{Employees}

Another constituency that can be considered providers of capital consists of employees of the company as investors of human or intellectual capital. Although in the traditional shareholder-stakeholder debate, both employees and creditors are considered stakeholders and therefore stand on a different footing from shareholders, that analysis is not relevant for the purpose of determining the mission of a company in the microfinance business. While examining the role of capital providers, the incentives of the capital providers are of relevance in steering the MFI toward either financial sustainability goals or toward creating social impact, or a more desirable outcome which is an appropriate mix of both.

115 See Zern-shun Adam Chen, Securitizing Microcredit: The Implications of Securitization for Microcredit Institutions' Human Rights Missions, 39 ColuM. HUM. RTs. L. ReV. 757, 788 (2008) (observing that "[t]his poses difficulties for poor borrowers who face unpredictable events (such as natural disasters, adverse weather, theft, or family illnesses) that challenge their ability to repay their loans.”).

${ }^{116}$ As Chen notes:

[T] here is no single party that a borrower can approach to change the terms of the loan in order to avoid default. The borrower cannot turn to the investors for several reasons: they are passive owners, there are many of them, and poor borrowers generally lack the resources to contact them. The [MFI] that originated the loan has relinquished its ability to change the terms of the loan. This information barrier prevents information flow between the two, which prevents them from working out deals.

Id. at 789 . 
Existing studies are sparse when it comes to the role of MFI employees and their individual goals in the microfinance sector. While some of the employees may be driven by social goals, it is expected that a vast majority of them are incentivized by the financial rewards of employment. The financial incentives of employees become even more acute when an MFI attains greater levels of commercialization. When private commercial investors such as private equity firms and venture capital funds take a position in a company, they rely on incentive-based schemes to compensate employees. Salaries are often set at low amounts, and a bulk of the compensation (especially at the senior levels) consists of "stock options or shares of restricted stock that vest over a period of time." 117 By aligning the interests of the employees with that of shareholders, employees are incentivized to perform their roles diligently and without shirking. However, such "earn-out" provisions are usually "stated in terms of earnings, the market value of the firm, or a combination thereof." 118 Employees are incentivized using financial performance criteria, and there are yet no indicia that measure the social performance of employees. This feature of employment contracts in firms (including MFIs) funded by commercial investors drives the organizations toward profitability and financial sustainability and dilutes the social impact goals.

Anecdotal evidence from India illustrates that some MFIs reward their senior employees in astoundingly generous terms. Sriram highlights the case of one MFI which compensated its CEO to the extent of Rs. 22.9 million (approximately $\$ 0.5$ million) in 2007-2008 that rapidly rose to Rs. 80.8 million (approximately US\$ 1.8 million) in 2008-2009.119 These salaries are disproportionate not only to the microfinance sector which is oriented toward achieving greater social impact, but even to the mainstream commercial financial sector. ${ }^{120}$ Commercialization of microfinance in countries such as India has seen a manifold increase in executive compensation, especially for senior management.

Employee stock options might be particularly attractive to incentivize

\footnotetext{
${ }^{117}$ Robert P. Bartlett, III, Venture Capital, Agency Costs, and the False Dichotomy of the Corporation, 54 UCLA L. REV. 37, 53 (2006).

${ }^{118}$ Robert M. Kossick, Jr. \& Julian Fernandez Neckelmann, Structuring Private Equity Transactions in Mexico, 6 NAFTA L. \& BUs. Rev. AM. 105, 140 (2000).

119 Sriram, Commercialisation of Microfinance in India, supra note 17, at 69 (adding that "[t]he remuneration paid to the [CEO] was around 7\% of the total personnel cost . . . in 2007-08 and shot up to $15 \%$ of the personnel cost in 2008-09.”). Sriram also highlights another company where the CEO was provided stock grants that he was able to liquidate for a profit of Rs. 143.2 million (approximately US\$ 3.2 million) prior to the company's public offering. Id. at 71 .

${ }^{120}$ Author's interview with a microfinance industry professional in India: May 12, 2011. In the comparable year of 2008-09, the annual compensation of the CEO of India's largest private commercial bank was at Rs. 18.4 million (approximately US\$ 0.41 million), only a fraction of the MFI CEO's compensation referred to earlier. See ICICI BANK LIMITED, $15^{\mathrm{TH}}$ ANNUAL REPORT AND ACCOUNTS 65 (2008-2009), available at http://www.icicibank.com/aboutus/annual-09.html.
} 
Microfinance and the Corporate Governance Conundrum

employees in listed MFIs. For example, SKS Microfinance, which listed its stock on Indian stock exchanges mid-2010, devised a number of employee stock option plans to reward its employees. ${ }^{121}$ While this is a useful method of incentivizing employees to perform well, the disadvantages of stock options as a form of employee compensation are only too well known in the aftermath of the global financial crisis. Employee stock options are found to have promoted short-termism among employees at the cost of a more long-term approach. ${ }^{122}$

This short-termism is especially harmful to MFIs. Since benefits from holding options are realizable only if the MFI performs financially, which is in turn reflected in the stock price, stock options motivate employees to focus on profitability of the MFI. In contrast, there is no evidence of MFIs benchmarking performance against social goals as opposed to financial parameters to devise employee stock options. Thus, stock options create an incentive structure which promotes a focus on profit without regard to the problems of poverty for which the microfinance industry was conceived of in the first place.

\section{Taking Stock of Capital Providers’ Incentives}

For-profit institutions engaged in commercial microfinance rely on contributions from different types of capital providers. Such capital providers possess varied incentives for participating in microfinance activity. These incentives play a significant role in the manner in which MFIs manage to define the dual missions of financial sustainability and social impact and work toward them. Figure 3 contains a summary of various capital providers' incentives in the MFI's business.

\footnotetext{
121 SKS Microfinance LtD., PRospectus 40-51 (Aug. 5, 2010), available at http://www.nseindia.com/content/equities/p_SKS.zip.

${ }^{122}$ See Ing-Haw Cheng et al., Yesterday's Heroes: Compensation and Creative Risk-Taking 7 (NBER Working Paper No. 16176, 2010), available at http:// www.nber.org/papers/w16176.pdf; Lucian Bebchuk, Alma Cohen \& Holger Spamman, The Wages of Failure: Executive Compensation at Bear Stearns and Lehman 2000-2008, 27 Yale J. on Reg. 257 (2010). As Bebchuk and Fried note:

Consider an executive who expects to be rewarded at the end of a given year based on performance measures tied to the stock price at the end of that year. This compensation structure may lead to two types of undesirable behavior. First, managers may take actions that boost the stock price in the short run, even if such actions would destroy value in the long run. For example, executives may enter into transactions that improve the current bottom line but create large latent risks that could cripple the firm in the future. Second, managers may engage in financial manipulation or other forms of "window dressing" that do not build firm value merely to pump up short-term prices. In both cases, executives receive higher pay even though they fail to build firm value. And in the first scenario, executives receive more pay even though they destroy firm value. Thus, rewarding executives for short-term results not only fails to serve the goal of encouraging executives to improve firm performance-it can actually work in the opposite direction. Lucian A. Bebchuk \& Jesse Fried, Paying for Long-Term Performance 6 (Harvard Law \& Econ. Discussion Paper No. 658, 2009), available at http://ssrn.com/abstract $=1535355$.
} 
Fig. 3

Incentives of Capital Providers to MFIs ${ }^{123}$

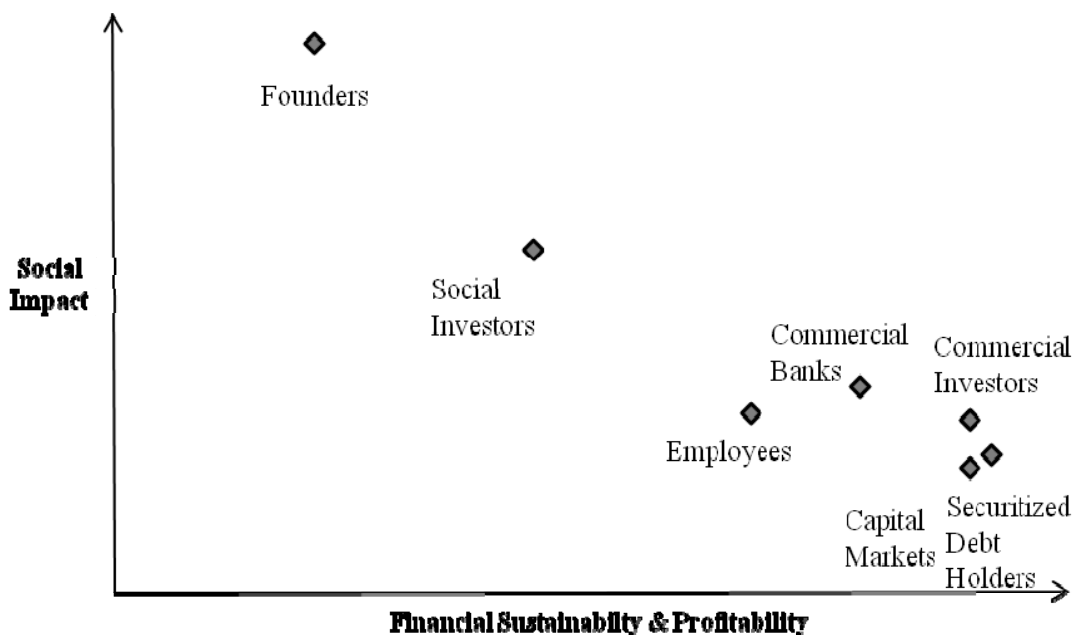

As we have seen, a large section of capital providers are incentivized primarily by commercial returns from microfinance (represented by the "Financial Sustainability \& Profitability" axis in Figure 3). For them, microfinance is just another asset or loan class, and their decision-making process and incentive structure for investing their resources is driven in the same manner as they would for investments in other businesses. Social goals, if at all, are secondary in nature and treated as a bonus: contributing to the welfare society while earning returns is welcome as an added advantage even if that is not foremost on their agenda.

That is not to say that commercial microfinance is completely devoid of social character. As we have seen, founders of MFIs continue to pursue their social goals albeit on a commercial scale. A growing band of social investors (who are willing to forego financial returns to achieve broader social impact) is beginning to make its presence felt in the microfinance industry, as it has been in other social sectors. Founders and social investors are high on the "Social Impact" axis in Figure 3. However, as this Article demonstrates, the mere presence of these socially minded constituents in the MFI set-up is insufficient to arrest the mission drift.

${ }^{123}$ The model presented here is simplified and intended only to provide an overview; as such, it is not set to any precise scale. 
Microfinance and the Corporate Governance Conundrum

\section{THE HORIZONTAL DIMENSION}

In this Part, I explore the relationship between MFIs and their customers. From a governance standpoint, it is necessary to determine the nature and extent of microfinance's social impact. Although microfinance and poverty alleviation tend to be inextricably linked in the microfinance discourse, there is need for caution. Existing literature does not present any evidence that microfinance is a cure for poverty. ${ }^{124}$ On the other hand, it has been argued that "MFI and donor hype has created the impression that microfinance is a cure for poverty." ${ }^{\prime 25}$ At best, microfinance may reduce BoP customers' vulnerability to poverty and act as part (but not the whole) strategy toward povertyreduction. ${ }^{126}$ Nevertheless, the fact that microfinance, if administered appropriately, has some benefits to BoP customers remains unchallenged.

\section{A. Social Impact of Commercial Microfinance}

Commercialization of microfinance seeks to use a market-based profitable model to serve BoP customers that brings about inclusive growth. A key tangible objective is to eliminate money-lenders who have traditionally lent to the poor at "loan-shark rates." ${ }^{127}$ In that sense, commercial microfinance seeks to tread the middle-path, whereby it lends to BoP customers on terms that are more favorable than money-lenders but less favorable than commercial banks (whose outreach to BoP customers tends to be low). The availability of credit (in terms of outreach) is as important as the terms on which it is provided to BoP customers. ${ }^{128}$

While much has been said about the social goals of MFIs, precisely how does one identify and measure performance against those goals? Unlike financial sustainability, which can be determined on the basis of objective factors, social goals are benchmarked against proxies that measure outreach.

${ }^{124}$ Aminur Rahman, Microcredit and Poverty Reduction: Trade-Off Between Building Institutions and Reaching the Poor, in LIVELIHOOD AND MiCROFInANCE: ANTHROPOLOGICAL AND SOCIOLOGICAL PerspeCtives on SAVINGS AND DeBT 39 (Hortze Lont \& Otto Hospes ed. 2004) (noting that although the "evidence suggests that microcredit can have positive effects on the poor, but that in many cases the impacts are insignificant or even negative.”).

${ }^{125}$ Hulme, supra note 5, at 28.

${ }^{126}$ As Hulme comments on the use of microfinance as a poverty-reduction strategy:

This is a potentially dangerous line of argument as it distracts attention from the fact that poverty reduction requires action on many fronts-social safety nets for the poorest and most vulnerable, an effective education system, low-cost and reliable health services, governments that can provide social inclusion (and thus maintain law and order) and sound macroeconomic policies, and many other issues. Id.

127 Kenneth Anderson, Microcredit: Fulfilling or Belying the Universalist Morality of Globalizing Markets?, 5 YALE HUM. RTS. \& DEV. L.J. 85, 95 (2002).

${ }^{128}$ Proponents of microfinance argue that it is desirable to ensure availability of credit to BoP customers as they are not served by the traditional banking sector, even though the terms may be more onerous to customers due to the high cost in delivering credit to them. See infra note 137, and accompanying text. 
For instance, emphasis is placed on whether the MFI lends using the individual lending method or the group lending method; ${ }^{129}$ whether the loan sizes are larger or smaller; ${ }^{130}$ whether the number of borrowers is larger or smaller; ${ }^{131}$ whether the customers are women or men. ${ }^{132}$

Using these parameters mentioned above, there is some evidence of mission drift through commercialization. One study notes that commercial microfinance is more likely "to involve an individual lending method, larger loans, fewer women customers, lower costs per dollar lent, higher costs per borrower, and greater profitability," ${ }^{133}$ while microfinance activity carried on a nonprofit basis by NGOs and developmental organizations is likely to be "employing a group lending method, giving smaller loans, serving more women, employing subsidies more heavily, facing higher costs per dollar lent, and being less profitable."134

Although the body of empirical literature reviewing the social impact of commercial microfinance is still at its nascent stage, the available evidence suggests that commercial microfinance could have a negative impact on the achievement of social goals. At the same time, the commercial microfinance sector has recently come under attack for exploiting the poor. In the following sub-parts the Article examines the merits of these claims with reference to two aspects that have received greater attention: interest rates and collection practices.

\footnotetext{
${ }^{129}$ In the individual lending method, loans are granted to individual borrowers much like the commercial banking sector. The group method "uses self-formed groups of customers that assume joint liability for the repayment of loans given to group members. The joint liability contract can, in principle, mitigate moral hazard and adverse selection by harnessing local information and enforcement possibilities ...." Cull, Demirguc-Kunt \& Morduch, Financial Performance and Outreach, supra note 11, at F108. This method is understood to have been pioneered by the Grameen Bank in Bangladesh, and it has been the subject matter of a number of academic studies. See e.g., Rashmi Dyal-Chand, Reflection in a Distant Mirror: Why the West Has Misperceived the Grameen Bank's Vision of Microcredit, 41 STAN. J. INT'L L. 217 (2005).

${ }^{130}$ Smaller loan sizes are indicative of lending to the poorer customers, while larger loan sizes suggest the borrowers are relatively well-off.

${ }^{131}$ Larger number of borrowers representing the portfolio of an MFI is an indication that the MFI has greater coverage in terms of outreach in being able to meet the needs of a greater section of the population.

${ }^{132}$ One of the key features of microfinance has been its focus on women. See Shana Hofstetter, The Interaction of Customary Law and Microfinance: Women's Entry into the World Economy, 14 WM. \& MARY J. WOMEN \& L. 337 (2008); Elissa McCarter, Women and Microfinance: Why We Should Do More, 6 U. MD. L.J. RACE, RELIGION, GENDER \& ClASS 353 (2006).

${ }^{133}$ Cull, Demirguc-Kunt \& Morduch, Microfinance Meets the Market, supra note 15, at 189.

${ }^{134} I d$. In an earlier study, the same authors found less evidence of mission drift. Cull, Demirguc-Kunt \& Morduch, Financial Performance and Outreach, supra note 11, at F131 ("Financially self-sustaining individual-based lenders tend to have smaller average loan size and lend more to women, suggesting and pursuit of profit and outreach to the poor can go hand in hand. There are however countervailing influences: larger individual-based and group-based lenders tend to extend larger loans and lend less frequently to women.”).
} 
Microfinance and the Corporate Governance Conundrum

\section{B. Interest Rates}

What is the appropriate interest rate to be charged on loans to the poor? That is indeed a vexing question. ${ }^{135}$ On the one hand, there is merit in the argument that $\mathrm{BoP}$ customers must be charged subsidized rates given their circumstances. A large part of the nonprofit sector in the microfinance industry adopts that approach. On the other hand, for the MFIs to be financially sustainable, they ought to be generating sufficient profits to attract capital. The revenues must be sufficient to cover the costs of maintaining and growing a portfolio. ${ }^{136}$

The proponents of commercialization of microfinance argue that BoP customers are abundantly capable of paying high interest rates. For instance, some commentators state that "the issue for the poor is not being able to pay a commercial interest rate (or even greater), but it is having access to credit in the first place." ${ }^{\circledR 37}$ Furthermore, they contend that interest rate is a function of the cost of delivery of microfinance and does not relate only to earning profits. ${ }^{138}$ Providing BoP customers with access to credit in far-flung areas can be costly due to high operating expenses, which is reflected in the interest rates. ${ }^{139}$ One study shows that if interest rates were lowered or capped by regulation, a substantial part of microfinance players will be out of business. ${ }^{140}$

The opponents of for-profit microfinance call for a cap on interest rates. The cap, they say, can be a percentage above the cost of funds, being the cost incurred by the MFI to procure funding that is used to lend to BoP customers. ${ }^{141}$ By linking interest rates to such a cost-plus model, MFIs will need to strive to maintain a tight leash on their operational expenses. Greater control over operational expenses will result in higher profitability of the MFI's

${ }^{135}$ There is tremendous variation in the interest rates charged. One study shows that "[a]t the median, nongovernmental organizations charge their borrowers 25 percent per year, while the top quarter charge 37 percent per year or more. Banks, at the median, charge just 13 percent per year at the median and 19 percent or more for the top quartile.” Cull, Demirguc-Kunt \& Morduch, Microfinance Meets the Market, supra note 15, at 182. That study also found a sharp contrast in that Compartamos charged an average interest rate of 90 -plus percent in the year 2007. Id.

${ }^{136}$ Anderson, supra note 127, at 101-02.

${ }^{137} \mathrm{Id}$. at 102 (emphasis in original) (citing THE NEW WORLD OF MICROENTERPRISE FINANCE: BUILDING HEALTHY FinANCIAL INSTITUTIONS FOR THE POOR 20 (Maria Otero \& Elisabeth Rhyne eds.,1994)).

${ }^{138}$ See, Megan Whittaker, South Africa's National Credit Act: A Possible Model for the Proper Role of Interest Rate Ceilings for Microfinance, 28 Nw. J. INT’L L. \& Bus. 561, 563 (2008).

139 Adrian Gonzalez, Sacrificing Microcredit for Unrealistic Goals, MicroBANKING Bulletin (Jan. 2011), available at http://www.themix.org/publications/microbanking-bulletin/2011/01/sacrificingmicrocredit-unrealistic-goals.

${ }^{140}$ A study relating to data from MFIs in India from 2003 to 2010 finds that if interest rates are capped at twenty-four percent and return of assets are capped at three percent, then almost half of the prevailing outreach for the sector will disappear by 2010. Gaul, supra, note 98.

${ }^{141}$ For instance, Professor Yunus argues that the interest rate should not exceed fifteen percent of the cost of funds, and that the "ideal "spread" between the cost of the fund and the lending rate should be close to 10 percent.” Muhammad Yunus, Sacrificing Microcredit for Megaprofits, N.Y. TIMES (Jan. 14, 2011). 
business. In other words, going by this approach, operational expenses impact profitability and therefore affect capital providers of an MFI. Since they do not increase interest rates, higher expenses are not passed on to the BoP customers.

The effect of interest rates on BoP customers is significant. Empirical studies point to the fact that "the poor react very proactively to lower-priced microfinance." 142 Consequently, they are likely to be worse-off paying commercial interest rates than they would be under a subsidized regime. ${ }^{143}$ The argument that microfinance interest rates are more favorable than moneylender interest rates may not cut much ice, and the justification of higher interest rates toward greater scalability "effectively rests on a very shaky moral imperative." 144 It does not result in an equitable outcome.

A high interest rate on microfinance also sparks off the moral hazard problem, particularly because borrowers are poor and provide no collateral for their borrowings. As one study notes:

Specifically, when lenders face informational asymmetry and borrowers lack collateral, charging interest above a certain threshold could aggravate problems of adverse selection and moral hazard. At high enough rates, only low-quality borrowers that do not expect to be able to repay would find it in their interest to borrow. If the conjecture is true, microbanks charging relatively high interest rates should expect to face lower repayment rates and profitability. ${ }^{145}$

While high interest rates may have a commercial justification in terms of making microfinance available on a broader and scalable basis, the negative impact of these higher rates affects not only the BoP customers, but also the MFIs themselves through moral hazard and informational asymmetry problems. ${ }^{146}$ Finally, even where high interest is justifiable both commercially and morally, the microfinance industry has not performed a good job of communicating the methodology of computing interest rates. Greater transparency on interest rates and other terms of microfinance could have possibly avoided the confusion that currently shrouds the appropriateness of commercial microfinance interest rates. ${ }^{147}$

\footnotetext{
${ }^{142}$ BATEMAN, supra note 24, at 56.

${ }^{143} \mathrm{Id}$. at 55 .

${ }^{144} \mathrm{Id}$. at 56 .

${ }^{145}$ Cull, Demirguc-Kunt \& Morduch, Financial Performance and Outreach, supra note 11, at F121.

${ }^{146}$ Although the microfinance industry has historically claimed a stellar repayment track-record, recent events in some countries such as India have highlighted difficulties in ensuring conformance with borrowers' obligations under high-interest bearing microloans. See, Part V(C) below for examples pertaining to difficulties of recovery.

${ }^{147}$ For example, MFIs could be more forthcoming with information and disclosures regarding their cost of funds and profitability, and the manner in which they compute their interest rates. Given that the
} 
Microfinance and the Corporate Governance Conundrum

\section{Rate of Recovery; Collection Practices}

Historically, the microfinance industry has relied upon the novel method of collective loans, where small groups of borrowers ensure payment of loans granted to individual members, which is essential due to a lack of collateral in microlending. ${ }^{148}$ Although collective loans continue to dominate the field, individual lending has also been rapidly rising. In both cases, the commercialization of microfinance has raised the specter of coercive collection problems. ${ }^{149}$ It has been alleged that MFIs in the for-profit sector provide incentives to their officers in the field for collecting installments on time thereby distorting any social impact. ${ }^{150}$ An episode that played out in the Indian state of Andhra Pradesh during late 2010 is reflective of the lack of accepted collection practices for the microfinance sector. ${ }^{151}$ While most of the MFIs in that state are said to have acted responsibly, some of them have possibly indulged in coercive collection methods that have tarnished the image of the for-profit microfinance sector. ${ }^{152}$

A somewhat related moral dilemma that arises is the use of commercial expectations toward exploitation of the poor. Risky lending, onerous terms, and coercive collection practices begs the question whether microfinance is being thrust on communities that are otherwise not in a position to meet the terms and honor the obligations. Lately, parallels are being drawn between the "microcredit bubble" 153 and the subprime mortgage crisis, ${ }^{154}$ with discussions

consumers of MFIs are unlikely to financially literate, they could be educated on the impact of borrowing at such interest rates in comparison with borrowing from other sources.

${ }^{148}$ See Dyal-Chand, supra note 129, at 254.

${ }^{149}$ As one commentator observes: "For a for-profit sector to anchor its whole business model on a 98 per cent plus rate of recovery is to provoke serious scepticism." Subir Roy, Lessons for Micro-finance from 2010, BUS. STANDARD, Jan. 5, 2011.

${ }^{150}$ See Savita Shankar \& Mukul G. Asher, Microfinance Sector in India: Which Way Now? 40 ASCI Journal of Management 17 (2011), available at http://journal.asci.org.in/Vol.40(201011)/40_2_Savita\%20Shankar.pdf.

${ }^{151}$ There were allegations of coercive collection methods practiced by certain industry players that even resulted in at least a dozen borrowers committing suicides as they were unable to bear the harassment. Yoolim Lee \& Ruth David, Suicides in India Revealing How Men Made a Mess of Microcredit, BlOOMBERG MKTS. MAG., Dec. 28, 2010. It must be noted, however, that the microfinance industry has put up its own defense against these allegations, and there is no evidence that the suicides were directly a result of coercive collections.

152 While there is no uniformity in the literature regarding the meaning of "coercive collection practices", it refers to loan recovery practices that "cross the line of legality" and where repayments are collected "aggressively and sometimes violently.” Intellecap White Paper, supra note 9, at 7.

${ }^{153}$ BATEMAN, supra note 24, at 140.

${ }^{154}$ Pamela Das, Avoiding a Subprime-Like Crises in Microfinance: Lessons from the Mexican and Bolivian Experience, 15 L. \& Bus. REV. AM. 819 (2009) (arguing that the exploitation of the poor by businesses is "a driving force that was clearly present in the collapse of the subprime credit market."). 
about Bolivia and Andhra Pradesh, India being at the forefront. ${ }^{155}$ Subprime loans were complex, opaque, and deceptive to borrowers. ${ }^{156}$ While microloans are relatively simple and straightforward, the difference is that BoP customers may not be fully apprised of their own financial circumstances and abilities because a vast majority of them are uneducated and even illiterate. Although microloans are small in size thereby arguably diffusing risk, the lack of collateral to support these loans offsets their small size that continues to make them risky. The fears of a subprime-like crisis in the microfinance sector may perhaps be exaggerated, but the lessons from the previous crisis cannot be ignored in setting the appropriate incentives to various players such that the industry can aim toward a "win-win" situation.

In sum, a discussion surrounding the horizontal dimension examining the relationship between the MFIs and their BoP customers suggests that while profitability is an important factor in ensuring scalability and outreach, the tendency of commercial microfinance players to ignore the social impact could lead to a crisis situation. Although most of the MFIs have acted responsibly, the deviance exhibited by a few players does not bode well for the entire industry, thereby staking the reputation and credibility of the sector as a whole.

\section{THE EXTERNAL DIMENSION}

This Part focuses on the influence of competition and state regulation on MFIs. The approach of MFIs toward their own governance and orientation toward either commercial or social goals depends upon the manner in which they react to these influences. As discussed below, the influences of competition and state regulation have distorted effects on the microfinance business when compared to their influence on commercial businesses generally.

\section{A. Competition}

Conventional wisdom suggests that competition in a sector enhances the marketplace for products and services. ${ }^{157}$ It has a positive effect on customers by making available a wider menu of options representing superior quality and at lower prices. In the microfinance sector, this translates into greater outreach into previously uncovered areas, lower interest rates, and flexibility in other terms. However, the microfinance sector has experienced effects from competition that are somewhat unusual. This is due to certain specific factors that operate in the sector, which are captured by empirical studies as well as anecdotal evidence.

\footnotetext{
${ }^{155}$ BATEMAN, supra note 24, at 140.

${ }^{156}$ Das, supra note 154 , at 840.

${ }^{157}$ Andrei Shleifer \& Robert Vishny, A Survey of Corporate Governance, 52 J. Fin. 737 (1997).
} 
Microfinance and the Corporate Governance Conundrum

First, competition ensues between different types of players with differing objectives. NGOs, government institutions, commercial banks, and MFIs all compete in the microfinance markets with varying goals and approaches. ${ }^{158}$ For example, the approach of socially-motivated lenders may increase outreach, while for-profit institutions may aim toward borrowers who are better able to repay the microloans. One study looks "for a relationship between competition and a profitability-outreach trade-off"159 and postulates that in a scenario of pure competition the for-profit institutions are likely to migrate to larger and wealthier borrowers, while nonprofit institutions aiming for welfare of $\mathrm{BoP}$ customers are likely to succeed in greater outreach. ${ }^{160}$ That study indicates that overall competition in the microfinance sector results in greater outreach determined through smaller loan sizes and greater lending to women. ${ }^{161}$

An earlier study explores the impact of competition on microfinance more directly. It finds that competition between MFIs "within the subset of profitable borrowers reduces the ability of a socially motivated lender to generate rents that support lending to the poorest and potentially least-profitable borrowers. The diminution of the capacity to cross-subsidize means that the poorest borrowers in the client-maximizing portfolio are dropped as competition

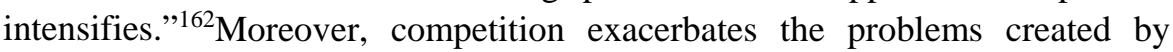
information asymmetry when MFIs are unable to monitor and share information about borrowers. ${ }^{163}$ This results in BoP customers taking on multiple loans that increase their indebtedness to potentially dangerous levels. These conclusions are supported by anecdotal evidence. Problems of information asymmetry and multiple lending are said to have contributed substantially to the crisis in Andhra Pradesh. ${ }^{164}$

${ }^{158}$ Cull, Demirguc-Kunt \& Morduch, Microfinance Tradeoffs, supra note 32, at 15-17.

${ }^{159}$ Id. at 16.

${ }^{160} \mathrm{Id}$.

${ }^{161} I d$. However, in this study competition was only one of the factors examined while considering the tradeoff between sustainability and social impact. Id.

${ }^{162}$ Craig McIntosh \& Bruce Wydick, Competition and Microfinance, 78 J. DEv. Econ. 271, 272 (2005).

${ }^{163}$ As McIntosh \& Wydick enunciate:

A ... negative effect of MFI competition originates from the likelihood of increasing asymmetric information between lenders. With a greater number of lenders in a market, we would expect information sharing between lenders to become more difficult, all else equal. We show that this creates an incentive for some (impatient) borrowers to take multiple loans. Such instances of multiple contracting both increase average debt levels among borrowers in the portfolio ... This makes all patient borrowers worse off, and again results in the poorest borrowers being dropped from the loan portfolio. In general, our results show that while wealthier and impatient borrowers are likely to benefit from increasing competition among MFIs, very plausible conditions exist under which an increase in the number of lenders in a market will lower the welfare of ... both the poor and the patient.

Id. One method in which the problem of information asymmetry can be tackled is through active involvement of credit information bureaus that track information about borrowers. However, the microfinance industry has not witnessed any meaningful participation by the credit information bureaus.

164 CGAP, Andhra Pradesh 2010, supra note 9. An added peculiarity with respect to competition in microfinance is that the sector is geographically concentrated. Competition has added to greater access 
Juxtaposing the effects of competition on the dual mission of MFIs, we find that while it is not entirely clear if competition improves profitability, ${ }^{165}$ its impact on outreach is somewhat distorted. Competition has not brought about greater outreach in a manner that benefits BoP customers.

\section{B. Regulation and the State}

The level of regulation of the microfinance sector is another external factor that influences the manner in which MFIs deal with the dual missions. ${ }^{166}$ While the for-profit microfinance sector is regulated in many countries, in others they are not subject to any specific regulation at all and they are regulated under the general law governing banks or non-bank institutions. ${ }^{167}$ Where regulated, MFIs are treated either as commercial banks ${ }^{168}$ or non-banking finance companies. ${ }^{169}$

The effects of regulation on the microfinance sector generate curious results on the dual mission problem as they do for competition. Although regulation can be expected to bring down costs through streamlined processes, the available evidence points to the contrary. Subjecting MFIs to regulation increases the costs of operation. While it is not clear whether the increased cost impacts profitability, ${ }^{170}$ studies suggest that regulation correlates negatively with outreach. MFIs with high costs of supervision and compliance reduce their outreach by shifting away from BoP customers who are more costly to serve. ${ }^{171}$ On the other hand, nonprofit institutions in similar circumstances sacrifice their

to microcredit in areas where microfinance is popular, and there has been little conscious effort to extend the benefits of microfinance activity to other regions.

${ }^{165}$ Cull, Demirguc-Kunt \& Morduch, Microfinance Tradeoffs, supra note 32, at 16.

${ }^{166}$ While regulation of the microfinance sector is an extensive topic by itself and raises a number of issues, I confine myself in this Article to the regulatory influences of dual mission and how that in turn affects corporate decision-making from a governance standpoint.

167 Mamiza Haq, Mohammad Hoque \& Shams Pathan, Regulation of Microfinance Institutions in Asia: A Comparative Analysis, 4 Int'l Rev. of Bus. Papers 421 (2008). A study in Europe reports that "only two countries, France and Romania, have specific legislation on microcredit. In other countries microcredit is regulated under the laws governing the institutions that provide it, basically banks and non-banks.” European Commission, Enterprise and Industry, Expert Group Report: The Regulation of Microcredit in Europe (Apr. 2007), available at http://ec.europa.eu/enterprise/newsroom/cf/ _getdocument.cfm?doc_id=538.

${ }^{168}$ For example, in Indonesia MFIs are regulated similar to banks. CHARITONENKO \& AFWAN, supra note 22, at 25-29.

${ }^{169}$ For example, India’s central bank, the Reserve Bank of India, regulates MFIs as non-banking finance companies and subjects them to supervision and prudential regulation. Reserve Bank of India, Master Circular on Microcredit, Feb. 14, 2011, available at http://www.rbi.org.in/scripts/ BS_CircularIndexDisplay.aspx?Id=6266.

${ }^{170}$ Cull, Demirguc-Kunt \& Morduch, Microfinance Tradeoffs, supra note 32, at 14; Robert Cull, Asli Demirguc-Kunt \& Jonathan Morduch, Does Regulatory Supervision Curtail Microfinance Profitability and Outreach? (Pol'y Research Working Paper No. 4748, 2009) [hereinafter Cull, Demirguc-Kunt \& Morduch, Regulatory Supervision], available at http:/www.nyu.edu/projects/morduch/documents/ articles/2009-06-Does-Regulatory-Supervision-Curtail-MF.pdf.

${ }^{171}$ Id. 
Microfinance and the Corporate Governance Conundrum

profitability to maintain outreach. ${ }^{172}$ Regulation therefore induces behavior whereby MFIs favor profitability over outreach-perhaps not an intended result.

Regulation of the for-profit microfinance sector is accompanied by certain other abnormalities. In many instances, the state itself is a player in the sector in addition to being a regulator. Several subsidized microfinance programs are spearheaded by the government, and it therefore competes directly with the forprofit companies for BoP customers. ${ }^{173}$ Governments therefore indulge in rentseeking behavior in regulating the for-profit microfinance sector. ${ }^{174}$ Anecdotal evidence of this tendency can be found in the decision of the Andhra Pradesh state government in India to impose onerous obligations on the for-profit microfinance industry in that state. ${ }^{175}$ As the conditions imposed by the new law made it financially unviable for MFIs to carry on business, the commercial microfinance sector has nearly come to a standstill. ${ }^{176}$

The perception that commercialization of microfinance allows MFIs to profit from the poor has provided ample ammunition to the state to seek tighter regulation of, and controls over, the for-profit microfinance sector. ${ }^{177}$ Politicians and bureaucrats have taken up the cudgel against the for-profit sector: since the microfinance sector serves the poor and underprivileged, the political mileage it provides is substantial enough to attract a great amount of interest. MFIs have seemingly not done enough to address these perceptions. ${ }^{178}$ While networks and associations of MFIs have sought to allay fears in the

${ }^{172}$ Cull, Demirguc-Kunt \& Morduch, Regulatory Supervision, supra note 170, at 27.

${ }^{173}$ CGAP, Andhra Pradesh 2010, supra note 9.

${ }^{174}$ M.S. Sriram, Microfinance: A Fairy Tale Turns into a Nightmare, XLV ECONOMIC \& PolitiCAL WEEKLY 10, 13 (Oct. 23, 2010).

175 On October 15, 2010, the Andhra Pradesh Government promulgated the Andhra Pradesh MicroFinance Institutions (Regulation of Money Lending) Ordinance, 2010 to impose stringent conditions on the for-profit sector. The restrictive conditions imposed by the Ordinance include "the requirement to register each branch of an MFI, allowing only monthly repayment of loans, and that too only at prominent Government facilities, and requiring MFIs to obtain prior approval of the registering authorities before granting a loan to an [self-help group] member." Shankar \& Asher, supra note 150, at 8-9.

${ }^{176}$ The crisis also galvanized the Reserve Bank of India (RBI) to examine the issue on a nation-wide basis. A committee appointed by the RBI issued its report in 2011 suggesting comprehensive measures to regulate the industry. These measures are being considered for implementation by the Government. A detailed discussion of the recommendations is outside the scope of this Article.

177 The language used in the preamble to the Andhra Pradesh Ordinance is reflective of how the government perceives of the for-profit sector in that state:

Whereas these [self help groups (SHGs)] are being exploited by private Micro Finance Institutions (MFIs) through usurious interest rates and coercive means of recovery resulting in their impoverishment \& in some cases leading to suicides, it is expedient to make provisions for protecting the interests of the SHGs, by regulating the money leading transactions by the money lending MFIs and to achieve greater transparency in such transactions in the State of Andhra Pradesh. ANDHRa PRADESH, ANDHRA PRADESH MiCROFINANCE INSTITUTIONS ORDINANCE (Oct.15, 2010).

${ }^{178}$ See Krishnamurthy Subramanian, Saving Microfinance from the MFIs, Fin. EXPRESS (May 9, 2011). 
minds of the politicians, bureaucrats, and the public, ${ }^{179}$ they are still far from experiencing any success. ${ }^{180}$ The disturbing outcome of such episodes is that while the ideological battles continue between the government and the forprofit microfinance sector, they arrest the flow of financial services to BoP customers who have been hitherto excluded from mainstream financial services. ${ }^{181}$

In all, the external factors of competition and state regulation affect MFIs' activities to a large extent. While both are intended to reduce cost to the customer, the effects are somewhat at odds with the intent. The external factors impose significant pressure on the MFI sector that reduces outreach and achievement of social goals. They do not appear to strengthen the move toward a "win-win" situation.

\section{BOARD STRUCTURE AND PRACTICES IN MFIS}

After examining the various dimensions-vertical, horizontal, and external-that define the relationship between MFIs and their constituencies, the Article now proceeds to determine the manner in which boards of MFIs operate to synthesize the differing interests of these constituencies, particularly in identifying and resolving them so as to adopt a defined strategy toward the dual missions. In doing so, the Article seeks to establish that the existing board structure and practices governing MFIs are no different from those governing other commercial businesses and the differences, if any, in the for-profit microfinance sector governance are only marginal in nature due to influences from founders and social investors.

\section{A. Theoretical Framework; Corporate Governance Discourse}

At the outset, the role of MFI boards in addressing dual missions is concerned with the extensive debate between the "shareholder-centric" approach to corporate governance and the "stakeholder" approach to corporate governance. ${ }^{182}$ The "shareholder-centric" approach states that shareholders as

\footnotetext{
${ }^{179}$ Two industry bodies representing the microfinance industry in India, being Microfinance Institutions Network (MFIN) (http://www.mfinindia.org/) and Sa-Dhan (http://www.sa-dhan.net/), have attempted to consolidate industry efforts by issuing codes of conduct for their members that deal with issues such as over-indebtedness and coercive collections. See Intellecap White Paper, supra note 9.

${ }^{180} \mathrm{Id}$.

${ }^{181}$ Id. at 7.

182 The theoretical debate surrounding this issue has been summarized as follows:

Variously described as communitarian versus contractarian, the Berle v. Dodd debate, the shareholder paradox, or the separation thesis, these differing visions reflect conflicting
} 
Microfinance and the Corporate Governance Conundrum

residual owners of a company deserve the greatest attention of corporate law. ${ }^{183}$ The "stakeholder" approach, on the other hand, seeks the protection of corporate law for other corporate stakeholders, including the environment, employees, and local communities. ${ }^{184}$ The United Kingdom has adopted the middle-path of an "enlightened shareholder value" approach wherein the protection of stakeholders is considered "as critical to generating long-term shareholder wealth." 185

For our limited purpose of examining the dual missions in the governance of MFIs, it is necessary to consider the extent to which corporate governance pays attention to the interests of BoP customers as stakeholders. ${ }^{186}$ Many concerns have been expressed in the legal academy about conferring rights to stakeholders. Stakeholders are heterogeneous in nature, and it is impossible to coherently identify their interests. ${ }^{187}$ If boards seek to protect the interests of multiple constituencies, inefficiencies are bound to creep into the decisionmaking process. ${ }^{188}$ On the other hand, the "shareholder-centric" approach that makes boards accountable to shareholders as the sole constituency provides clarity in that it is capable of being judged against a single norm, which is shareholder value represented by the performance of the stock price of the company. ${ }^{189}$ Similarly, critics of the stakeholder approach argue against appointment of directors in order to cater to the interests of specific constituencies of stakeholders. It is feared that special interest or constituency directors will cause fissures on the board thereby impeding collective decisionmaking and "balkanizing" the board. ${ }^{190}$

While all of the objections to the general stakeholder approach to corporate governance may be valid, they do not carry any weight in the context of dual

political and moral preferences concerning the nature of corporations. Most famously the debate is reflected in the sharply contrasting views of Milton Friedman and his many critics.

Thomas W. Dunfee, Corporate Governance in a Market with Morality, 62 LAW \& CONTEMP. ProBs. 129, 130 (1999).

183 The classic case of Dodge v. Ford Motor Co., 170 N.W. 668, 684 (Mich. 1919) states that the business of a company is carried on primarily for its shareholders, and that directors cannot divert profits for other purposes (such as to benefit customers). See also Milton Friedman, The Social Responsibility of Business Is to Increase its Profits, NeW York Times Magazine, Sept. 13, 1970.

${ }^{184}$ Andrew Keay, Stakeholder Theory in Corporate Law: Has it Got What it Takes?, 9 RiCH. J. GLOBAL L. \& BUS. 249, 257-58 (2010).

185 Virginia Harper Ho, "Enlightened Shareholder Value": Corporate Governance Beyond the Shareholder-Stakeholder Divide, 36 J. CORP. L. 59, 60 (2010).

${ }^{186}$ Although the traditional shareholder-stakeholder debate includes creditors and employees within the larger body of stakeholders, the present analysis of corporate governance of MFIs using the three dimensions treats them as providers of capital, and in that sense similar to shareholder interests. See supra, Part III.

${ }^{187}$ See Ho, supra note 185, at 108.

${ }^{188}$ Stephen M. Bainbridge, The Case for Limited Shareholder Voting Rights, 53 UCLA L. REV. 601, 608 (2006).

${ }^{189}$ Ho, supra note 185 , at 108.

${ }^{190}$ Lipton \& Rosenblum, supra note 93, at 82-83. 
missions on MFI boards. As far as MFIs are concerned, and going by the horizontal dimension of governance discussed earlier, there is only one stakeholder constituency, which is represented by the BoP customers and the communities to which they belong. Customer interest is capable of clear definition, and does not suffer from the heterogeneity problem that critics of the stakeholder theory constantly underscore. Boards are required to balance the interests of capital providers on the one hand and BoP customers on the other. Objections to the stakeholder theory of corporate governance therefore do not come in the way of providing specific recognition to the interests of BoP customers and their communities. Such an approach will make inroads in resolving the dual missions of MFIs. With this theoretical background, the Article now proceeds to discuss existing trends emanating from practices on MFI boards that enable a greater understanding of corporate governance issues in the for-profit microfinance sector.

\section{B. Board Composition and Focus}

The board of an MFI essentially consists of representatives of investors. Although it is common under corporate law for equity investors to choose the board members, in certain circumstances lenders may have powers under contract to nominate members of the board. ${ }^{191}$ Board members of MFIs can be divided into four categories. First, the founder of the MFI is almost always a director, usually in an executive capacity as a CEO and sometimes as a nonexecutive chairperson. ${ }^{192}$ Second, professional executives, who may be appointed on the board, are in charge of the day-to-day management of the MFI. ${ }^{193}$ Third, private investors (both commercial and social) nominate their representatives to the board. These directors exercise their role not only to make available their strategic expertise to the MFI but also to ensure that the investment of the shareholder that nominated them is protected. ${ }^{194}$ Fourth, MFIs do appoint outside directors, who are neither founders, managers nor nominees of investors. They are inducted to bring in an outside independent perspective to the board. A number of leading jurisdictions require boards to be populated by "independent" directors and some of the outside directors may

\footnotetext{
${ }^{191}$ Lender nomination of board members is common in India. See, e.g., State Bank of India Act, Act No. 23 of $1955 \S 35 \mathrm{~A}$ (1955). This phenomenon extends to the microfinance sector as well, with Small Industries Development Bank of India (SIDBI), a leading government lender in India that is active in lending to MFIs having a number of its nominees on MFI boards.

192 Labie, supra note 44, at 297 (noting that effectively run the organization even after commercialization and they find it hard to give up their managerial or leadership role).

193 This situation may occur when the founder director does not take up an executive role in the MFI.

194 Commercial investors such as private equity investors and venture capital firms tend to hold substantial, and sometimes controlling, stakes in MFIs, which provides them with substantial influence over the affairs of the MFIs.
} 
Microfinance and the Corporate Governance Conundrum

serve that purpose as well. ${ }^{195}$ As a separate category, it is also possible that stakeholders such as employees and customers may be represented on MFI boards. While senior managers who are also on the board tend to represent employee interests, it is unusual to find direct representation of customer interests. In the microfinance sector, BoP customers do not have the necessary knowledge and skills to represent themselves on boards, and therefore do not find direct participation on MFI boards. ${ }^{196}$

The background of the directors and expectations regarding their role influence the direction of the organization along the financial sustainabilitysocial impact continuum. Matters are somewhat complicated because of the heterogeneity in board interests, and the "mixed profile" of the directors. ${ }^{197}$ Founder directors tend to be visionaries with a keen interest on creating social impact. ${ }^{198}$ Some also represent the voice of the BoP customers, being the key stakeholders, on the board. ${ }^{199}$ Professional executives, on the other hand, may not share the same perspective. They are usually hired for their business skills and financial industry expertise, and tend to pay greater importance to issues of financial sustainability. This often creates a mismatch of mission and approach. ${ }^{200}$ Nominees of investors and lenders are driven by profitability and financial sustainability. This is particularly the case with nominees of private equity investors, venture capital firms, and commercial bank lenders. Social

${ }^{195}$ Although the requirement to appoint "independent" directors (who have no pecuniary relationship with the company, its management or substantial shareholder) applies only to listed companies, several privately held companies have also adopted the practice primarily with an eye to listing in the near-term.

${ }^{196}$ Council of Microfinance Equity Funds, The Practice of Corporate Governance in ShareholderOwned Microfinance Institutions 10-11 (May, 2005), available at http://www.accion.org/Document.Doc?id=571.

${ }^{197}$ Labie notes:

$\ldots$ in this type of organization, combining different types of shareholders may generate a certain incoherence in the priorities of the organization. If not, it can create tension between groups when deciding organizational priorities. Indeed, one can easily understand that historical mixed-profile shareholders and the ones joining the organization after it is institutionalized do not naturally share the same priorities or, if they do, the two groups do not give the same importance to their various priorities.

Labie, supra note 44, at 297. Labie's reference to shareholders can very well include other capital providers too, as their objectives differ as well leading to further complexities.

${ }^{198}$ CGAP, Effective Governance for Microfinance Institutions, FOCUS NOTE No. 7 (1997), available at http://www.microfinancegateway.org/gm/document-1.9.28522/1811_1811.pdf. This is particularly the case where the MFI is the result of a transformation from an NGO. Board members of NGOs are usually inducted for their community experience in the relevant field. Hishigsuren, supra note 16, at 24; Sanjay Sinha \& Frances Sinha, Sustainability and Development: Evaluating the Performance of Indian

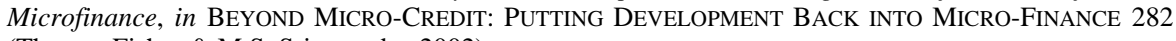
(Thomas Fisher \& M.S. Sriram eds., 2002).

199 Email dated May 2, 2011 from the founder CEO of an MFI in India to the author (on file with author).

${ }^{200}$ A highly publicized episode that illustrates this point relates to disagreements between the founder chairman and professional CEO of SKS Microfinance regarding the strategic direction of the company immediately following its public offering and listing. See Capitalism vs. Altruism, SKS Rekindles the Microfinance Debate, INDIA KNOWLEDGE@WHARTON, Oct. 7, 2010, http://knowledge.wharton.upenn .edu/india/article.cfm?articleid=4533 (last visited Feb. 26, 2012). 
investors are expected to adopt a dual mission approach, although there is insufficient evidence regarding their behavior on MFI boards. Outside directors contribute their special expertise in the sector and other strategic inputs, and in the case of listed MFIs they are also expected to perform a monitoring role.

Overall, since for-profit institutions are subject to greater prudential and other regulation, concerns of financial sustainability and solvency are foremost. Management of financial resources is an important objective, and hence MFI boards seek expertise in the fields of finance, strategic management, law, and regulation. ${ }^{201}$ For this reason, boards are overwhelmed with experts from these disciplines. ${ }^{202}$

With such differing objectives, achieving a unified approach on the board in terms of the dual missions is a daunting task. With a substantial collective shareholding, private commercial investors tend to play a significant role on MFI boards with their emphasis on profitability. ${ }^{203}$ Moreover, private investors and their nominees are likely to act in a manner creates the best possible value for themselves. In doing so, there is a serious risk that individual interests of investors conflict with overall institutional interests, which may be sacrificed in the process. ${ }^{204}$ Such differences in interests may also be disruptive at an organizational level. ${ }^{205}$ Although founder directors focus on social impact, it is not clear if they are able to pursue their goals to the fullest extent given that founder directors in most MFIs do not hold a significant enough stake to play a dominant role in comparison to private investors. ${ }^{206}$

\section{Incentives of Board Members}

For-profit institutions in the microfinance sector tend to provide incentives such as stock options and stock purchase rights to directors, including outside

\footnotetext{
${ }^{201}$ One survey indicates that the most common skills represented on MFI boards are financial skills, and that microenterprise expertise only came second. Anita Campion, Current Governance Practices of Microfinance Institutions: A Survey Summary 27 (1998), available at http://www. microfinancegateway.org/gm/document-1.9.26102/1401.pdf.

${ }^{202}$ A number of practitioners interviewed for this Article stated that the orientation of directors is often determined by the individuals occupying the position rather than the specific type of investors they represent. For instance, it is not uncommon to find nominee directors of commercial investors to take a keen interest on social issues and vice versa.

${ }^{203}$ Interview evidence from Indian MFIs reflects that board deliberations are dominated by matters of financial sustainability and minimally in terms of social impact.

${ }^{204}$ Council of Microfinance Equity Funds, supra note 196, at 7.

${ }^{205} \mathrm{Id}$.

206 Thomas Fisher, Emerging Lessons and Challenges, in FISHER \& SRIRAM, supra note 198, at 356. This is unlike commercial firms in developing countries where founders (sometimes known as promoters) are controlling shareholders and play a significant role in the governance of the firm. See Rafael La Porta, Florencio Lopez-de-Silanes \& Andrei Shleifer, Corporate Ownership Around the World, 54 J. FIN. 471 (1998); Ronald J. Gilson, Controlling Shareholders and Corporate Governance: Complicating the Comparative Taxonomy, 119 HARV. L. REV. 1641 (2005).
} 
Microfinance and the Corporate Governance Conundrum

directors, in a manner similar to how such institutions incentivize employees. ${ }^{207}$ The benefit of such an approach is that it aligns the interests of directors and shareholders. However, it causes short-termism in board actions. Focus is placed entirely on profitability and enhancement of stock price that enables directors to liquidate their shares when the price is sufficiently attractive. Critics of such an approach have argued that such a reward system "does not appear suitable for a company, particularly for one with a lofty mission statement." ${ }^{208}$

\section{Performance Reporting}

The performance of an MFI is monitored by the board on the basis of available information. Corporate and securities laws perform an informationforcing function whereby companies are compelled to compile and disclose information regarding their affairs, which not only informs their shareholders and other stakeholders, but also enables the board to rely on such information to monitor the performance of management. Conventional principles of corporate law place undue emphasis on the reporting of financial information, as this process is intended to enable shareholders to make informed decisions regarding their investment in the company. Corporate laws provide detailed disclosure norms regarding financial information, and provide formats for communication such as the balance sheet, profit and loss statement, and cash flow statement. ${ }^{209}$ This is equally true in the case of MFIs, which are structured as commercial corporations. Under corporate law, MFIs are required to report on financial matters, and hence there is tremendous emphasis on analyzing financial performance as parameters are sufficiently disclosed. Thus, financial sustainability has received substantial attention. ${ }^{210}$

However, when it comes to social impact, companies generally have no legal obligation either to maintain such information or to communicate it to stakeholders in general. The United Kingdom has made some inroads on this count, where the Companies Act of 2006 requires listed companies to include in their directors' report information about "social and community issues."211

${ }^{207}$ For example, see SKS MiCROFINANCE LTD., supra note 121.

${ }^{208}$ Sriram, Commercialisation of Microfinance in India, supra note 17, at 72.

${ }^{209}$ See for example Sections 211 and 212 of Companies Act, 1956, India; Chapter 4, Annual Accounts, Companies Act, 2006, UK.

${ }^{210}$ See Susy Cheston \& Larry Reid, Measuring Transformation: Assessing and Improving the Impact of Microcredit, 1 J. MiCROFINANCE 21 (1999) (finding that the microfinance sector relies on financial reporting even though it does not achieve the sector's objectives, and that is only because financial measures are easier to calculate with a greater sense of accuracy). See also Janet E. Kerr, Sustainability Meets Profitability: The Convenient Truth of How the Business Judgment Rule Protects a Board's Decision to Engage in Social Entrepreneurship, 29 CARDOZo L. REV. 623, 643 (2007).

${ }^{211}$ UK Companies Act, 2006, c. $46 \S 417$ (Eng.). Although the United Kingdom was expected to prescribe detailed reporting requirements with respect to stakeholder impact pursuant to provisions of the Companies Act, that had to be withdrawn due to lack of support. Demetra Arsalidou, The 
As far as the microfinance sector is concerned, there are no defined parameters to determine social impact. MFIs are therefore not well-positioned to track their performance against social impact goals. For example, one survey indicates that the frequency of financial reporting by an MFI was far greater than reporting on social impact statistics. ${ }^{212}$ The strong market-based forces that favor financial reporting make it difficult for MFIs to stay focused on social goals. ${ }^{213}$

The survey of the corporate governance practices in this Part VII suggests that it is hard for MFIs to maintain the dual missions. The market-based approach toward microfinance tends to veer strongly toward financial sustainability without paying adequate attention to the social impact. In such a scenario, the "win-win" situation largely remains in the realm of rhetoric.

\section{ALTERNATIVE CORPORATE GOVERNANCE FRAMEWORK FOR MFIS}

In this Part, the Article sets out some normative suggestions that may enable the commercial microfinance movement to bridge the schism between financial sustainability and social impact. Microfinance will have to be treated as a social enterprise that is judged by different standards, a field that is to be occupied by capital providers with a long-term focus and lesser expectations on commercial returns, and one where social goals are not forsaken.

\section{A. Clarity of Corporate Purpose and Mission}

MFIs must clearly define their mission, which forms the basis for their activities. ${ }^{214}$ The mission can be contained in the corporate charter so as to obtain legal sanctity. A precise articulation of the social goals will ensure that the performance of the MFI can be measured against well-defined parameters. It will also identify the interests of the various stakeholders, and in turn refine the duties of the MFI's board. Directors need not fear action from shareholders or other capital providers for failure to remain profitable and reward shareholders so long as they pursue social goals (outlined in the mission) in good faith. They will be "protected by the business judgment rule as long as they are informed in their decision making process."215

Withdrawal of the Operation and Financial Review in the Companies Bill 2006: Progression or Regression, 28(5) COMP. LAW. 131 at 131 (2007).

${ }^{212}$ Campion, supra note 201, at 34.

${ }^{213}$ Council of Microfinance Equity Funds, supra note 196, at 4.

${ }^{214}$ See Todd Arena, Social Corporate Governance and the Problem of Mission Drift in SociallyOriented Microfinance Institutions, 41 CoLUM. J.L. \& Soc. PROBS. 269, 302 (2008).

${ }^{215}$ Leslie Dougherty, Putting Poverty in Museums: Strategies to Encourage the Creation of the ForProfit Social Business, 29 B.C. THIRD WORLD L.J. 357, 367 (2009). See also Arena, supra note 214, at 303; Kerr, supra note 210, at 635-39. The business judgment rule "is a presumption that in making a business decision the directors of a corporation acted on an informed basis, in good faith and in the honest belief that the action taken was in the best interests of the company.” Aronson v. Lewis, 473 A. 2d 805, 812 (Del. 1984). 
Microfinance and the Corporate Governance Conundrum

\section{B. Moderating the Expectations of Capital Providers}

Microfinance is a social enterprise. If the dual missions are to be realized, investor expectations in the microfinance sector must be tempered. The pursuit of profitability must not come at the cost of social goals. Investors must be willing to accept lesser returns in this sector than from an entirely commercial enterprise. Commercial investors ought not to crowd out social investors who have moderate expectations on returns. A similar trend must occur in the case of lenders and, to some extent, employees.

The microfinance sector must be serviced by capital providers with longterm interests. Investors must not be permitted to enter and exit MFIs to make quick profits. This is particularly so in the case of publicly listed MFIs where short-termism can distort the incentives of investors. For example, investors in the microfinance sector, whether commercial or social, could be required to remain invested in the company for a specific period of time in order to ensure that only long-term investors are committed to such investments. ${ }^{216}$ With the growth of the social and philanthropic investment vehicles, the level of interest in such investments is only likely to grow.

In terms of public listings, the microfinance sector can carve a separate market for itself such that each MFI is judged only against its peers and not against other comparable companies in the banking and finance sector. This will eliminate the pressure on MFIs to demonstrate profitability on the same scale as other commercial firms in the same sector. The idea of creating a separate publicly traded MFI index would benchmark each MFI against the sector, such that the dual missions are recognized and adhered to. ${ }^{217}$

\section{Enhanced Focus on Social Impact}

The existing corporate governance regime for MFIs pays attention almost entirely to the vertical dimension, consisting of the relationship between the MFI and its capital providers. There is a considerable lack of focus on the horizontal dimension, i.e. the relationship between MFI and its BoP customers. A number of measures may be taken by reexamining the corporate governance framework in order to provide greater social orientation. ${ }^{218}$

First, the corporate governance framework for MFIs could specify the role

\footnotetext{
${ }^{216}$ At the same time care must be taken to ensure that long-term investors do not enter into derivatives and other synthetic transactions by which they transfer their economic risk to other short-term investors. ${ }^{217}$ Bhakti Mirchandani \& Alexandra Connell, Gauging and Hedging the Upside-The Need for a Publicly Traded MFI Index, 27 J.L. \& CoM. 209 (2009) (discussing the concept of an MFI index, although not particularly with reference to the dual missions).

${ }^{218}$ It is beyond the scope of this Article to deal with possible changes as to the terms on which MFIs contract with the BoP customers or the manner in which they enforce such terms against the customers. For example, this Article does not advocate any cap on interest rates or a cap on return on assets or any collection methods that may be considered acceptable industry practice.
} 
of the board in focusing on the social mission by providing customer representation. As discussed earlier, ${ }^{219}$ direct customer representation on MFI boards is unviable. The outside directors appointed on MFI boards could discharge their social responsibility by promoting and focusing on the interests of the BoP customers. ${ }^{220}$ The board as a whole can deliberate on the social impact of the MFI's business strategies. In order to ensure transparency in the board process, MFIs may be required to publish a social impact statement discussing the effect of key strategic decisions on customers and how the MFI has maintained its social goals. These steps would address concerns of mission drift at an organizational level.

Second, measures must be adopted to judge the performance of the organizational as well as individual directors and officers using a mix of financial and social parameters. The concept of a "balanced scorecard" has been identified as a mechanism that tracks performance across multiple parameters, not just financial. ${ }^{221}$ By giving managers a holistic perspective of the business, it requires them to consider the interests of stakeholders such as customers in the decision-making process. Similarly, reporting systems must also move beyond mere financial reporting. There has been a significant evolution of norms on environmental, social, and governance (ESG) reporting, particularly within the social investing community. ${ }^{222}$ In the microfinance sector, the focus has been shifting toward social impact assessments, where development goals such as women's empowerment, rural outreach, and social responsibility to clients are considered. ${ }^{223}$ Recommendations have been made for improvement of indicators that track the availability of non-financial services, general training to BoP customers, client retention, consumer protection principles, and social responsibility to customers and line-staff. ${ }^{24}$

${ }^{219}$ See supra Part VIIB.

${ }^{220}$ Das, supra note 154, at 842-43; see Arena, supra note 214, at 306 (highlighting that such "social” directors can be drawn from the pool of impact assessment researchers, social scientists and the like); M.S. Sriram, An Agenda for Reinvention and Reincarnation, THE MinT (Dec. 13, 2010). A unique example is that of Ujjivan, an MFI in India, which has constituted a committee of directors referred to as the "Social Performance Management Committee" whose "objective is to oversee social program undertaken by the Company and monitor economic \& social impact on customer.” UJJIVAN FINANCIAL SERVICES PRIVATE LTD., ANNUAL REPORT 2009-10 34 (2010), available at http://www.ujjivan.com/ pdf/Ujjivan-Annual-Report2009-10.pdf.

221 See Robert S. Kaplan \& David P. Norton, The Balanced Scorecard-Measures That Drive Performance, HARV. BuS. REV., Jan.-Feb. 1992, at 71-79. See also Amir N. Licht, The Maximands of Corporate Governance: A Theory of Values and Cognitive Style, 29 DEL. J. CORP. L. 649 (2004).

${ }^{222}$ See Ho, supra note 185, at 80-81 (noting also that ESG reporting is supported by economic rationale because a continued focus on ESG matters could lead to better long-term returns for investors). For a discussion of the metrics being discussed to measure social impact generally, see Kerr, supra note 210, at 642-54.

${ }^{223}$ An early study lists the key features of available impact studies. Cheston \& Reed, supra note 210, at 31-38.

${ }^{224}$ Adrian Gonzalez, Microfinance Synergies and Trade-offs: Social versus Financial Performance Outcomes in 2008 15, MIX DATA BRIEF No. 7, available at http://www.themix.org/sites/default/files/ 
Microfinance and the Corporate Governance Conundrum

All of these parameters will have to weigh heavily in determining the social performance of MFIs. Such measures are necessary to ensure that sociallyfocused MFIs are not overly relying on efficiency, portfolio quality, and productivity by forsaking their social goals. ${ }^{225}$ One of the reasons financial parameters gain preference is their uniformity and comparability. If social parameters are to gain greater relevance, they have to absorb these features. It is for participants in the microfinance sector to develop uniform principles of defining and measuring social impact such that they attain the position of industry standard to be utilized uniformly by all participants. ${ }^{226}$

\section{Method of Regulating Corporate Governance in MFI}

Since commercialization of microfinance and the emergence of for-profit institutions in the sector have been of recent vintage, there is yet no uniform approach toward corporate governance in MFIs. Given the inconsistencies in approach as highlighted in this Article, there is need for a well-defined set of corporate governance principles that apply uniformly to the microfinance sector.

Some broad principles come to mind. Government regulation of corporate governance in MFIs will be counterproductive due to its rigidity and must be avoided. Given the heterogeneity of the sector and its constant evolution, a mandatory "one-size-fits-all" approach is not recommended. ${ }^{227}$ The corporate governance framework must be voluntary in nature and must originate from the industry. Confederations of microfinance institutions, both at the international and national levels, may frame their own norms of corporate governance to be adopted by their member institutions. For instance, in India, the networks of MFIs represented by MFIN and Sa-dhan may issue their own governance framework after due deliberations. ${ }^{228}$

The governance framework for MFIs may follow a "comply-or-explain" approach $^{229}$ in the social sector, through the method of "self-regulation" as

MIX\%20Data\%20Brief\%207.pdf.

${ }^{225}$ Id. at 1. See also Council of Microfinance Equity Funds, supra note 196, at 4-5.

${ }^{226}$ It is noteworthy that a handful of MFIs have begun to focus on reporting social impact. For example, Ujjivan, an MFI based in India has included a detailed Social Performance Management report as part of its annual report required to be published under corporate law. See UJJIVAN ANNUAL REPORT, supra note 220. See also Dinesh Unnikrishnan, Focus on Social Objective, MFIs Told, THE MinT, Oct. 10, 2011; AbHiJt V. BANERJEe \& Esther Duflo, PoOR ECONOMics: A RADICAl RETHINKING OF THE WAY TO Fight GLOBAL POVERTY 170-71 (2011).

${ }^{227}$ See Arena, supra note 214, at 314.

${ }^{228}$ For further details regarding these networks, see supra note 179 . Although these networks have issued codes of conduct, they provide sparse guidance on issues concerning corporate governance. See Srinivasan, supra note 26 , at 86 . That is a key shortcoming and needs to be addressed in a timely manner.

${ }^{229}$ In this approach, companies are required to comply with the provisions of accepted corporate governance norms, or alternatively explain their governance approach. For a greater discussion, see 
opposed to mandatory government regulation. Suggestions have been made that "the concept of reflexive law, which provides stakeholders with access to information and documentation of statements to assist them in their decisionmaking rather than dictating the substance of those decisions, should guide government regulation of microfinance markets." ${ }^{230}$ The need for such a governance framework that balances financial and social concerns cannot be emphasized more.

\section{CONCLUSION}

The commercialization of microfinance has witnessed the transition of major players in the sector from nonprofit institutions to for-profit entities such as corporations. While commercialization has aided in scalability and outreach in order to widen the scope of financial inclusion to the poor communities, it has been accompanied by several issues and concerns. The excessive reliance on financial sustainability due to the adoption of market-based mechanisms has caused MFIs to turn their back on social goals. This has created a glaring perception in the minds of regulators and the public that private interests are benefiting from the vulnerability of the poor.

The existing investor-centric corporate governance framework has not helped MFIs to dispel that perception. There is a need for greater discourse on the shift from financial aspects of governance to the social aspects of governance. Unless there is timely action on this account through appropriate corporate governance mechanisms, the commercialization of microfinance may very well become a victim of its own success.

Anita Indira Anand, An Analysis of Enabling vs. Mandatory Corporate Governance Structures PostSarbanes Oxley, 31 DEL. J. CORP. L. 229, 229 (2006); Sridhar Arcot, Valentina Bruno \& Antoine FaureGrimaud, Corporate Governance in the UK: Is the Comply or Explain Approach Working? 1 (2009), available at http://ssrn.com/abstract $=1532290$.

${ }^{230}$ Arena, supra note 214, at 314. 